\title{
Racial Preferences in Higher Education: Political Responsibility and the Judicial Role
}

\author{
Terrance Sandalow $\dagger$
}

Controversy continues unabated over the question left unresolved by DeFunis $v$. Odegaard: ${ }^{1}$ whether in its admissions process a state law school may accord preferential treatment to certain racial and ethnic minorities. In the pages of two journals published by the University of Chicago, Professors John Hart Ely and Richard Posner have established diametrically opposed positions in the debate. ${ }^{2}$ Their contributions are of special interest because each undertakes to answer the question within the framework of a theory concerning the proper distribution of authority between the judiciary and the other institutions of government.

In the earlier article, Professor Ely defends the constitutionality of racial preferences, essentially on the ground that the equal protection clause should not be read to prevent a majority from discriminating between itself and a minority only to its own disadvantage. The predicate for an active judicial role is lacking, Ely essays to demonstrate, when the issue is whether a majority may "discriminate against itself," and, he concludes, resolution of the issue therefore ought to be left to the political process. ${ }^{3}$

Professor Posner, on the other hand, argues that the equal protection clause should be read to prohibit "the distribution of benefits and costs by government on racial or ethnic grounds." Ironically, Posner defends this judicial limitation of legislative power in part by arguing that a decision sustaining the constitutionality of minority preferences would intolerably augment the power of the judiciary to determine the direction of social policy. Courts must limit legislative power, as it were, in the service of democratic ideals.

+ Professor of Law, University of Michigan.

' 446 U.S. 312 (1974).

2 Ely, The Constitutionality of Reverse Racial Discrimination, 41 U. CHI. L. REv. 723 (1974) [hereinafter cited as Ely]; Posner, The DeFunis Case and the Constitutionality of Preferential Treatment of Racial Minorities, 1974 SUP. CT. REv. 1 [hereinafter cited as Posner].

3 Ely at $727,731-32$.

- Posner at 22. 
Neither position, in my judgment, adequately confronts the problem of the judicial role in a democracy. The value choices Posner would have the courts eschew are inescapable if the equal protection clause is to be employed as a measure of legislative power. Precisely because such choices are essential whenever the clause is used to limit legislative power, however, appropriate sensitivity to the values served by democratic decision-making requires courts to defer to legislative judgments unless they clearly transgress constitutional tradition. Nothing in American constitutional tradition requires courts to deny legislatures the power to authorize preferential admissions policies for racial and ethnic minorities. The validity of such policies depends only upon a judgment that they serve the public welfare. The arguments that can be advanced to support such a judgment are more than ample to sustain such an exercise of legislative power.

The precise question posed by DeFunis and like cases, however, is not whether preferential admissions policies are within the competence of a legislature, but whether they are valid when adopted by a university without explicit legislative sanction. There is, I shall argue, a significant difference between these questions, and because of that difference existing racial preference programs draw no support from Ely's analysis. Although there is good reason to sustain preferential policies in any event, the grounds for such a judgment are far less compelling than they would be if the policies had received explicit legislative approval.

\section{The Normative Basis of Equal Protection}

A decision whether government may adopt a policy of explicitly preferential treatment of racial and ethnic minorities requires a painful choice between ideals to which American society has developed a deep commitment, deeper than many of its critics assume. On the one hand, such a policy seems inconsistent not only with the nation's rejection of racism ${ }^{5}$ but with concepts of individuality and merit that are even more deeply rooted in Western culture. A rejection of minority preferences, on the other hand, seemingly threatens

${ }^{5}$ The suggestion that there has been a rejection of racism may seem overstated. Racial sentiment is obviously of continuing significance in the United States, a fact which I shall argue has an important bearing upon the question whether minority preferences ought to be held permissible under the equal protection clause. See text and notes at notes 93-106 infra. Nevertheless, evidence of the rejection of racism in American society is everywhere and overwhelming: in the mass of legislation against racial discrimination, in judicial decisions, in literature and schoolbooks, in the media of mass communications, and in the rhetoric of political leaders. 
both humanitarian and egalitarian ideals which also have deep roots in Western culture.

In discussing so vexing an issue, it is useful to begin with fundamentals, even at the risk of restating the obvious. The constitutional guarantee of "the equal protection of the laws," to begin at such a point, does not mean that everyone must be treated equally. The state may tax some individuals at a high rate, some at a low rate, and some not at all. It may maintain a system of publicly supported higher education which admits as students only those who meet established criteria. A prime function of law, indeed, is to mark out the bases for discrimination by government in its relations with the citizenry.

What the equal protection clause does require, stated in the most general terms, is that government treat similarly all those who are similarly situated. ${ }^{6}$ But as the literature of moral philosophy articulates more clearly than the literature of the law, the principle of similar treatment for those similarly situated-Aristotle's principle of distributive justice ${ }^{7}$-merely states a formal relationship. ${ }^{8}$ Standing alone, it is insufficient to decide any case because it does not indicate how to determine when individuals are similarly situated. All individuals are similar in some respects and different in others. The question that must be answered before it can be determined whether "the equal protection of the laws" requires similar treatment of different individuals is whether the differences among them ought to be taken into account. What is required, in other words, is a material or substantive principle, a standard by which to determine when the differences among individuals justify treating them differently.

Now the principle of similar treatment of those similarly situated is merely a prescription for rational behavior and, in that sense, value-free. ${ }^{9}$ But the material principles which determine whether individuals are similarly or differently situated necessarily rest upon value choices. A decision whether individuals are similarly or differently situated cannot be made "without positing a certain scale of values, a determination of what is important and what is not. It is our view of the world, the way we distinguish what has value from

- Tussman \& tenBroek, The Equal Protection of the Laws, 37 CaLIF. L. Rev. 341, 344 (1949).

7 Nicomachean Ethics, Bk. V.

3 See H.L.A. Hart, The Concept of Law 153-63 (1961); C. Perelman, The Idea of Justice ANd the Problem of Argument 1-87 (1963).

- See text at notes 13-14 infra. 
what has none," 10 that leads us to conclude whether individuals are similarly or differently situated. Controversy concerning the meaning of the equal protection clause is a product of disagreement not only about those values, but about how and by whom they ought to be determined.

When the issue is whether the administration of law comports with equal protection, the demands imposed by the concept of equal protection are clear. The material principle is provided by the law. Equal protection consists of adherence to its terms. If, for example, the law prescribes a ten percent tax on the income of all individuals, the principle of similar treatment for those similarly situated would be violated by a tax collector who levied a fifteen (or a five) percent tax only on blacks. The violation does not depend upon the use of a racial classification (either to the advantage or disadvantage of blacks), but upon the statute's stipulation that income differences alone are relevant to a determination of the taxes that individuals must pay. Thus, the principle of similar treatment for those similarly situated would also be violated if the tax collector were to levy a tax greater (or less) than ten percent upon the income of all individuals who have assets in excess of one million dollars. By stipulating that income differences are the only differences to be taken into account in determining taxes, the lawmaker has ruled out consideration of other differences, however much it might be wished that the tax collector were free to consider them. Wealth and race are equally irrelevant, not because either is in some sense intrinsically irrelevant to taxation, but because they have been made so by a particular material principle-the statute.

The meaning of the equal protection clause is much less clear when the validity of legislation is at issue. A claim that legislation denies the equal protection of the laws is an assertion that the legislation treats differently individuals who are similarly situated. Since the individuals are in fact different and the legislation does distinguish among them, the claim must be that there is a principle extrinsic to the legislation in virtue of which the affected individuals must be deemed similarly situated. ${ }^{11}$ But since that extrinsic principle cannot be derived from the formal principle of similar treatment for those similarly situated, the claim must be that the equal protection clause embodies one or more material principles from which it can be determined whether persons are similarly situated. ${ }^{12}$ Yet

${ }^{10}$ C. Perelman, supra note 8 , at 27.

"Cf. H.L.A. HART, supra note 8, at 157.

12 Other provisions of the Constitution might be invoked to support a conclusion that 
nothing in the language of the equal protection clause suggests the values that ought to be given expression by a substantive reading of the clause.

The use of the equal protection clause as a measure of the validity of legislation is thus attended by difficulties similar to those encountered when the due process clause is given substantive meaning. Judgment depends upon principles that are necessarily valueladen, principles that are an expression of views concerning the appropriate role of government in the society and, ultimately, proper ends of the society. No doubt, such premises are necessary whenever the constitution is involed to limit legislative power. Judicial review has been a persistent source of controversy for precisely that reason. The democratic commitment of our age requires-or at least has seemed to many to require-that important value choices rest with institutions that are more politically responsible than the courts. The judiciary's warrant for curbing legislative power is especially vulnerable when the limits that are imposed depend upon giving substantive meaning to the due process or equal protection clauses. The absence of a textual foundation for whatever substantive principles are proposed to be read into those clauses diminishes the likelihood that the necessary value choices are rooted in constitutional tradition and thereby weakens whatever claim the judiciary might have for withdrawing those choices from the other institutions of government. I do not mean to suggest that a substantive reading of the due process and equal protection clauses can never

certain characteristics must be ignored in determining whether persons are similarly situated. But then, as the late Justice Harlan pointed out in Shapiro v. Thompson, 394 U. S. 618,659 , 661-62 (1969) (dissenting opinion), the equal protection clause adds nothing to the analysis of a statute's validity. For example, if the religion clauses of the first amendment forbid consideration of religious affiliation, there is no need to invoke the equal protection clause in order to invalidate legislation that differentiates upon the basis of such affiliation. See also San Antonio Ind. School Dist. v. Rodriguez, 411 U.S. 1, 100 n.59 (1973) (Marshall, J., dissenting).

The equal protection claim is not similarly redundant when the material principle is derived from state legislation and the claim under the equal protection clause is that dissimilar treatment has been accorded individuals who are similarly situated under the legislation. To be sure, the equal protection claim raises the same issue as the claim that the statute has been violated. The claim that the statute has been violated, however, does not raise a federal question and, hence, would be beyond the competence of a federal court. The equal protection clause functions in these cases to give federal courts jurisdiction over claims that state law has not been administered in accordance with its terms. See, e.g., Raymond v. Chicago Traction Co., 207 U.S. 20 (1907). Not surprisingly, the extraordinary potential of this analysis for expanding federal review of the administration of state law has led the Supreme Court to formulate limiting doctrines, such as the doctrine that equal protection is not denied unless the failure to apply state law according to its term is systematic or intentional. See Snowden v. Hughes, 321 U.S. 1 (1944). 
be justified, but reasonable sensitivity to the values of democratic decision-making counsels that the courts proceed cautiously in reading those clauses to limit the choices available to government, especially the choices available to government in devising remedies for pressing social problems.

Perhaps because the justification for reading the equal protection clause as enacting any particular material principle is so problematic, equal protection analysis is often cast in terms that appear to obviate the need for such a principle. The Supreme Court has frequently stated, for example, that legislation offends the clause if there is no rational basis for the dissimilar treatment accorded different individuals. ${ }^{13}$ The emphasis upon rationality in this formulation may make it appear that there is no need for a material principle and, thus, that it is possible to determine the validity of legislation under the equal protection clause without making the value judgments that inhere in such a principle. The appearance is deceptive. A determination whether there is a rational basis for the legislative classification involves precisely the same inquiry as the determination whether the affected individuals are differently situated..$^{14}$ It would be irrational to decide differently two cases that are identical in all respects. But since no two cases are truly identical, the question of rationality is inseparable from the question of which differences are significant. Whether a legislative classification is rational depends upon a showing that individuals who are accorded different treatment are differently situated. And whether individuals are differently situated depends upon which differences are judged important in virtue of a particular material principle.

Judicial opinions are frequently written, nevertheless, to make it appear that the "rational basis" test can be employed without introducing an extrinsic material principle, simply by ascertaining whether the disparate treatment accorded individuals is justified by the purpose of the legislation..$^{15}$ The implicit claim is that a material principle is provided by the purpose of the legislation and that the judicial role is confined to ascertaining whether the means chosen by the legislature is rationally related to its objective. The attrac-

${ }^{13}$ See, e.g., Richardson v. Belcher, 404 U.S. 78, 81 (1971); Lindsley v. Natural Carbonic Gas Co., 220 U.S. 61, 78-79 (1911).

1 Cf. J. Feingerg, Social Philosophy 99 (1973).

${ }^{15}$ See, e.g., Eisenstadt v. Baird, 405 U.S. 438, 447 (1972); Reed v. Reed, 404 U.S. 71, 7576 (1971); Smith v. Cahoon, 283 U.S. 553, 563, 567 (1931). At times, it is said that the question is whether the classification can be justified by a permissible legislative purpose. See, e.g., Griffin v. County School Board, 377 U.S. 218, 231 (1964). The qualification, of course, introduces an extrinsic material principle. 
tiveness of this approach to equal protection determinations is obvious. ${ }^{16}$ Material principles rest upon judgments of value that are often controversial. Unless a particular choice of values is prescribed by constitutional tradition, a judicial determination seems incompatible with the nation's commitment to democratic decisionmaking. Invoking the purpose of the legislation seemingly avoids this difficulty by resting the determination whether individuals are similarly or differently situated upon a material principle-and therefore upon a choice of values-prescribed by the legislature. The role of the courts is limited to ascertaining whether the legislature has been true to its purpose. Public policy and the determination of social goals are left to the elected representatives of the people.

The flaw in this approach is that it cannot explain any decision invalidating legislation without attributing to the legislature a purpose distinct from that revealed by the terms of the legislation it has enacted. ${ }^{17}$ When the cases in which the approach has been employed to invalidate legislation are fully analyzed, it is apparent that an extrinsic material principle implicitly underlies each of the decisions. In Smith v. Cahoon, ${ }^{18}$ for example, the Supreme Court used the equal protection clause to invalidate a statute that required a security bond to be posted by all motor carriers except those transporting agricultural goods and certain seafoods. The Court had no doubt that increasing public security was a valid legislative purpose, but it held that there was no difference between carriers subject to the requirement and those exempt from it in relation to that purpose. If public security had been the legislature's only objective, the exemptions would indeed have been irrational in treating differently persons who, for this purpose, were similarly situated. ${ }^{19}$

But the very irrationality of the exemption on this supposition suggests that an increase in public security was not the only legislative objective. The mere existence of the exemption indicates that the legislature also intended to avoid placing additional burdens on the agricultural and seafood industries. The purpose of the legisla-

" See generally Gunther, Foreword: In Search of Evolving Doctrine on a Changing Court: A Model for a Newer Equal Protection, 86 Harv. L. Rev. 17 (1972).

17 See generally Note, Legislative Purpose, Rationality, and Equal Protection, 82 Yale L.J. 123 (1972) [hereinafter cited as YALE NotE].

in 283 U.S. 553 (1931).

1 See H.L.A. HART, supra note 8, at 158-59, J. FeinBerg, supra note 14, at 105. This conclusion is subject to the possibility that there may have been certain factual differences between the exempt carriers and all other carriers, e.g., that the former were more financially responsible or employed more careful drivers. The Court mentions no such factual justifica. tion. 
tion, in other words, was to increase public security without imposing additional costs on two favored industries. And in relation to that purpose the statutory classification was entirely rational. If the exemption in Smith $v$. Cahoon violated the equal protection clause it must therefore have been for some reason other than the irrationality of the statutory classification.

The inability of a "means-ends" analysis to explain the result in Smith $v$. Cahoon is not a consequence of factors unique to that case. All legislation that raises equal protection issues involves an accommodation of competing goals, each of which acts as a constraint upon the maximization of the others. None of the goals, standing alone, comprehends the purpose of the legislature, for that purpose is to achieve an optimal balance among competing goals. The potential multiplicity of legislative objectives means that it will always be possible to draw from the terms of a statute legislative purposes to which the statutory classification is rationally related. The burdens or benefits created by a statute suggest at the very least a purpose to burden or benefit all those who share the classifying characteristic. The statutory classification must be rationally related to that purpose because the purpose has been derived from the classification. "Legislative purpose so defined is nearly tautological but it also is the purpose suggested by the plain terms of a statute." ${ }^{20}$ A conclusion that legislation offends the equal protection clause cannot, therefore, be grounded solely upon a determination that the classifications employed in the legislation are not rationally related to the purpose of the legislation. Some extrinsic principle is needed to justify the conclusion that those to whom the legislature has accorded different treatment are, for constitutional purposes, similarly situated.

The need for such a principle is, however, a good deal more obvious than the warrant for any particular principle. ${ }^{21}$ Although

${ }^{20}$ YALE NOTE, supra note 17, at 128.

${ }^{21}$ In Smith v. Cahoon, for example, the Court may have implicitly determined that favoritism to the agricultural and seafood industries was not a permissible legislative objective. Assuming that the statutory classification could not have been supported by any other objective, the statute would then have violated the equal protection clause by according different treatment to carriers similarly situated in relation to permissible legislative objectives. The constitutional warrant for a principle precluding such favoritism is not obvious, however. To read into the Constitution a requirement that legislation serve interests more general than those of particular social and economic groups would intolerably augment the power of the judiciary to determine social policy. Surely Professor Posner is correct in suggesting that "[ $t]$ he real 'justification' for most legislation is simply that it is the product of the constitutionally created political process of our society." Posner at 29; $c f$. J. THAYER, LEGAL Essays 80 (1908). Even if so dubious-principle were read into the Constitution, the ques- 
the Supreme Court has in recent years frequently invoked the equal protection clause to invalidate legislation, it has not carefully considered the problem of justifying the material principles upon which those decisions rest. Several members of the Court, led by Mr. Justice Marshall, have urged that material principles can be derived from values expressed by other constitutional provisions. ${ }^{22} \mathrm{~A}$ majority of the justices have rejected that position but have failed to advance any other. ${ }^{23}$ Whatever the merits of Justice Marshall's theory in the cases to which it applies, a substantial number of the Court's recent equal protection decisions rest upon material principles that cannot conceivably be drawn from other provisions of the Constitution. ${ }^{24}$ The consequence is that we lack a substantive theory of equal protection-a theory that would define the interests that the clause protects and thereby confine its reach.

Professor Posner's argument in support of the principle that race is not a permissible criterion of governmental action, as discussed more fully below, ${ }^{25}$ rests largely upon his belief in the need for such a theory. The desire for such a theory is readily understandable. In its absence, there seems no alternative to resting equal protection determinations upon an assessment of the gains and losses resulting from the challenged legislation, with the judiciary exercising ultimate authority for determining what is a "gain" and what is a "loss." The opportunity thus conferred upon the judiciary to substitute its judgment for the legislature's on the relative merits of competing social goals is, after the past two decades, not simply a matter of conjecture. Yet, unless the courts are to abandon use of the equal protection clause as a measure of the validity of legislation, a move toward which neither the Supreme Court nor its critics seems disposed, weighing the relative merits of competing social goals is an inescapable element of adjudication. There is no way, apart from choosing among such goals, that the courts can deter-

tion whether the broader public interest is promoted by an implicit subsidy to certain industries is surely too intractable for adjudication in a constitutional setting. See YaLE Note, supra note 17 , at 144 .

22 See San Antonio Ind. School Dist. v. Rodriguez, 411 U.S. 1, 102-03 (1973) (dissenting opinion).

${ }^{23}$ Id. at 29-39 (opinion of the Court).

${ }^{24}$ See, e.g., Frontiero v. Richardson, 411 U.S. 677 (1973); Department of Agric. v. Moreno, 413 U.S. 528 (1973); Weber v. Aetna Casualty \& Surety Co., 406 U.S. 164 (1972); Williams v. Illinois, 399 U.S. 235 (1970). Other decisions rest upon material principles that are at best tenuously related to other constitutional provisions. See, e.g., In re Griffiths, 413 U.S. 717 (1973); Bullock v. Carter, 405 U.S. 134 (1972); City of Phoenix v. Kolodziejski, 399 U.S. 204 (1970).

${ }^{25}$ See text and notes at notes 71-89 infra. 
mine whether those who have received different treatment at the hands of the legislature are, for constitutional purposes, to be deemed similarly situated.

Nor is it feasible, over time, to confine the Court's role by adopting a theory which once and for all specifies the particular values that are to be accorded protection under the equal protection clause. Social change is inevitably accompanied by change in social values. "Any moral, social or political evolution leading to a modification in the scale of values," as the moral philosopher Chaim Perelman has written, "will at the same time modify the characteristics regarded as essential for the application of [the principle of similar treatment for those similarly situated]."26 The emergence of new values and the falling away of older ones leads to a continuous redefinition of the categories by which men perceive themselves and to continuous reassessment of the significance that they attribute to those categories. A theory of equal protection that prescribes unchanging categories must, over time, prove to be both too restrictive and insufficiently restrictive of legislative power. ${ }^{27}$

The necessity for choice among competing values in formulating the material principles required to give effect to the equal protection clause need not be taken as a carte blanche for the courts to substitute their judgment for that of the legislature on any and all issues of social policy. An awareness that judgments concerning the relative merits of competing public policies underlie the principles employed to determine whether individuals are similarly or differently situated may, indeed, temper the temptation for judges to substitute their judgments for those of the legislature. The more the value predicates of decision are brought to the fore, the more a court sensitive to the full range of values to which the Constitution gives expression will hesitate to upset a deliberate legislative choice. For among the values to which the Constitution gives expression are those associated with decision-making by politically responsible institutions. To be sure, "democratic" values are not the only values embodied in the Constitution, and constitutional tradition permits the courts to override legislative choice in the service of other goals. Yet due regard for "democratic" values requires that legislative

${ }^{26}$ C. Perelman, supra note 8 , at 27.

27 I do not mean to suggest that it is unnecessary to have a theory prescribing how to determine the values that are to be given expression through the equal protection clause. The Court's failure to develop such a theory, during a period of intense use of the clause, has left the law of equal protection in intellectual disarray. My point, rather, is that it would be unwise to adopt a theory of equal protection that purports to specify for the indefinite future the particular values to be protected. 
decisions be overridden only when those decisions are inconsistent with values society has come to view as fundamental.

The means by which the Court can accommodate these democratic values with the need to recognize evolution in the values to be accorded constitutional protection is, of course, the great question of constitutional law, a question which is not uniquely posed by the equal protection clause. In the concluding section of this paper, I want to suggest the beginnings-barely more than a hint - of an approach to that question. Before that, however, I want to show that constitutional tradition does not require that the equal protection clause be read to prohibit state-supported colleges and universities from adopting an admissions policy that accords preferential treatment to racial and ethnic minorities.

\section{Racial Discrimination and Constitutional Tradition}

Professor Posner argues that the equal protection clause should be read to prohibit "the distribution of benefits and costs by government on racial or ethnic grounds." 28 The intense controversy that has developed over the use of minority preferences demonstrates the lack of a societal consensus concerning the wisdom of such preferences. In the absence of a consensus, justification for a principle that would withdraw the controversy from the normal processes of political settlement depends, minimally, upon the persuasiveness of one of three lines of argument: (1) the principle expresses the intentions of those responsible for the adoption of the fourteenth amendment; ${ }^{29}$ (2) the principle can be derived from another, more general, and concededly valid principle of constitutional law; or (3) the principle must be recognized because it is necessary to justify other decisions that the Court would feel required to make under the

${ }^{28}$ Posner, supra note 2, at 22. Posner's principle extends beyond preferential admissions policies, prohibiting all consideration of race by government. In arguing that the principle ought not to be adopted by the Supreme Court, I do not mean to suggest that any "benign" use of a racial criterion ought to be sustained. Since the question whether different persons should be deemed similarly situated can be answered only in relation to the consequences of a course of action, the validity of a racial classification depends upon an evaluation of the consequences attendant upon its use. The consequences will, of course, differ for different governmental programs. See Kaplan, Equal Justice in an Unequal World: Equality for the Negro-The Problem of Special Treatment, Nw. U.L. REv. 363 (1966). The argument presented here may, of course, have some relevance in determining the validity of preferential treatment for minorities in other programs, but I have made no effort to think through all the problems for programs other than admission to institutions of higher education.

21 It is unnecessary to consider the extent to which "the intention of the draftsmen" alone can justify a constitutional principle because, as Posner concedes, the framers of the fourteenth amendment did not intend to imbed the principle he proposes in the Constitution. See text at notes 30-32 infra. 
Constitution. Posner's principle cannot, in my judgment, be persuasively supported by any one of these arguments.

\section{A. The "Legislative" History of the Equal Protection Clause}

The framers of the fourteenth amendment plainly did not intend to prohibit the states from employing a racial criterion to the advantage of the black population. Posner himself points out that "[s]o bizarre would discrimination against whites in admission to institutions of higher learning have seemed to the framers of the [f]ourteenth [a]mendment that we can be confident that they did not consciously seek to erect a constitutional barrier against such discrimination." 30 Nor did they have the broader intention of prohibiting all consideration of race by government. Thus, "it is equally clear," as Posner concedes, "that the framers did not contemplate that the [a]mendment would compel equal treatment of blacks in public education"31_or in a number of other areas either. ${ }^{32}$ The notion lately advanced by the Supreme Court and repeated by some commentators, that "[t]he clear and central purpose of the [f]ourteenth [a]mendment was to eliminate all official state sources of invidious racial discrimination in the States," ${ }^{33}$ is simply an anachronism-an attribution to the framers of the amendment of views that did not achieve currency until much later.

The idea that black and white are equal, that race is not a meaningful category, did not begin to gain ascendancy until well into the present century. ${ }^{34}$ Ideas that today would be labelled racist-the word did not exist in the nineteenth century-were during the nineteenth century the common property of the white population, North and South, educated and uneducated, slaveholder and abolitionist. Disagreements existed, of course, but the dominant sentiment of the time accorded race a significance that today, after the revolution in attitude during the past fifty years, seems almost beyond comprehension. Racial differences were perceived as fundamental, enduring and, almost always, reflecting the innate superiority of the white population. ${ }^{35}$

30 Posner, supra note 2, at 21-22.

si Id. at 22.

${ }^{32}$ See Bickel, The Original Understanding and the Segregation Decision, 69 HaRv. L. REv. 1, 58 (1955).

${ }^{33}$ Loving v. Virginia, 388 U.S. 1, 10 (1967). See also Cohen, Race and the Constitution, 220 The Nation 135, 138-39 (1975).

34 G. Frederickson, The Black Image in the White Mind 325-32 (1971); T. Gosset, Race 409-59 (1963); L. Litwack, North of Stavery (1961).

${ }^{35}$ See G. Frederickson, supra note 34; T. Gosset, supra note 34. 
In the intellectual milieu of the nineteenth century, the dominant question was not whether the races were different, but the significance of the fact that they were. During the years immediately following the Civil War, there was substantial sentiment, centered in the radical wing of the Republican party, that whatever differences might exist between blacks and whites were not relevant to their equality before the law. "[T] he question presented in these discussions," said Representative Baldwin of Massachusetts during debate on Reconstruction legislation, "is not a question concerning the equality or the inequality of human races . . . . [I]t is a question concerning human rights. It calls upon us to decide whether men shall be equal before the law and have equality in their relations to the Government of their country." ${ }^{36}$ But, as the late Professor Alexander Bickel demonstrated in his study of the origins of the equal protection clause, the radical Republicans were unable to carry their point, ${ }^{37}$ A rule that race was never to serve as a legally relevant category could not have gained the assent of the country, for it would have opened too wide a gap between the law and the understanding of the time.

The purpose of the clause was narrower, to gain for blacks equality with whites in respect of certain rights that were deemed necessary incidents of their status as free men. Mr. Justice Miller, writing for the Court shortly after the adoption of the Civil War amendments, stated the intention precisely in attributing to all of the amendments the "pervading purpose" of guaranteeing

the freedom of the slave race, the security and firm establishment of that freedom, and the protection of the newly-made freeman and citizen from the oppression of those who had formerly exercised unlimited dominion over him. ${ }^{38}$

Freedom, not equality, was the purpose of the equal protection clause.

This "legislative" history does not require rejection of the principle proposed by Professor Posner; the point is, rather, that it does not require adoption of that principle. As Posner suggests, the provisions of the constitution ought not to be confined to the precise meaning intended by their framers. But if it is undesirable to be governed by the past, it is worse to be ruled by a misconception of

3 Cong. Globe, 40th Cong., 2d Sess., pt. 1, 456 (1868). See generally G. Frederickson, supra note 34 , at $178-93$.

${ }^{37}$ Bickel, supra note 32.

3s Slaughter-House Cases, 83 U.S. (16 Wall.) 36, 71 (1873). 
the past. And only a misconception of the past leads to the conclusion that it imposes upon government an obligation of "colorblindness."

An understanding of the origins of the equal protection clause is useful also because it provides an historical illustration of the point, developed analytically in the first section of this paper, that the guarantee of "the equal protection of the laws" is only an affirmation of other values, of goals that must be determined independently of the rule of equality and, therefore, that require independent justification..$^{38}$ The framers of the fourteenth amendment accepted as an overriding value that blacks, solely by reason of their humanity, were entitled to be free. In that respect they were similar to whites and, therefore, entitled to similar treatment in respect of what were then conceived to be the necessary incidents of freedom. But blacks and whites were not perceived as alike in all respects, nor were all relationships between citizens and government thought to involve the value of freedom. When freedom and its incidents were not involved, there were other values, such as the intelligent discharge of civic obligations, in respect of which blacks and whites were thought not to be similarly situated and in respect of which discrimination was, therefore, justified. The goals the framers sought to achieve thus determined for them when racial discrimination was to be permissible. Today, similarly, a decision about whether racial discrimination is permissible will be determined by what we seek to accomplish.

\section{B. The Validity of Classification by Involuntary Characteristics}

A second way of justifying a principle is to demonstrate that it can be derived from a more general and concededly valid principle. The only readily apparent principle from which Posner's principle might derive is the suggestion by several members of the Supreme Court that classification on the basis of characteristics that are adventitious and immutable is, if not necessarily invalid, at least constitutionally suspect. ${ }^{40}$ The impulse that gives rise to this suggestion is not difficult to make out. It seems unfair that the burdens and benefits of social life, especially those distributed by government, should be apportioned among individuals on the basis of qualities over which they lack control. The denial of schooling to

${ }^{30}$ See also C. Perelman, supra note 8, at 55.

10 See, e.g., Frontiero v. Richardson, 411 U.S. 677, 682 (1973) (plurality opinion); $c f$. Weber v. Aetna Casualty \& Surety Co., 406 U.S. 164, 175 (1972). 
children because of their skin color or sex, the limitation of public office to certain families, and other familiar examples from history and literature suggest the force behind that idea. Ideally, these illustrations might be taken to suggest, distribution of the burdens and benefits of social life ought to bear some relationship to responsibility and merit.11 Yet, prevailing notions of responsibility and merit are intimately bound up with the opportunity for choice ${ }^{42}$ that is denied individuals when government classifies them on the basis of involuntary characteristics.

Professor Posner disclaims any reliance on this broader principle, however. As he correctly points out, a court could not consistently apply the principle that "no involuntary characteristic should ever be used as a criterion of public regulation." 43 The situations are too numerous in which the values of our society call for attention to involuntary characteristics. Those values may require efforts to cultivate (by incentives or otherwise) the use of what are, in part, genetic characteristics, as when rewards or special training are given to the intellectually gifted or those of unusual physical prowess. Humanitarian considerations may suggest special consideration for the needs of those who suffer from an involuntary disability, say, by devoting a larger amount of resources to the education of handicapped children than to the education of other children. Surely, none of these policies would be held by a court to be beyond governmental competence, ${ }^{44}$ as recognized even in the opinions that suggest the illegitimacy of classification by adventitious, immutable characteristics. In such situations, it is explained, the classifying characteristic is relevant to a legitimate governmental purpose. ${ }^{45}$ But that formula, of course, is the test for the validity of all classifications, not merely those which rest upon adventitious

"For a critique of this view, see J. Rawls, A Theory of Justice 310-15 (1971).

12 See I. Berlin, Four Essays on Liberty 63-81 (1969).

${ }^{13}$ Posner, supra note 2, at 23. See also Ely, supra note 2, at 730 n.36.

" Of course, the suggested principle holds only that classifications that rest upon adventitious, immutable characteristics are constitutionally suspect, not that they are necessarily invalid. The principle is nevertheless unsatisfactory if "constitutionally suspect" is understood as a term of art that triggers all the consequences outlined in the Supreme Court's opinions. See, e.g., Memorial Hospital v. Maricopa County, 415 U.S. 250, 263 (1974); Shapiro v. Thompson, 394 U.S. 618, 632-33 (1969). The virtual certainty that the Caurt would not hold discrimination in favor of handicapped children to be "suspect" suggests that what renders a classification "suspect" is not the nature of the criteria that are employed but the nature of the class that is disadvantaged. Cf. Note, The Right of Handicapped Children to an Education: The Phoenix of Rodriguez, 59 CoRnell L. Rev. 519 (1974). Adequate consideration of that possibility is beyond the scope of this paper, but the analysis in the concluding section suggests some of the issues raised by it.

ts Frontiero v. Richardson, 411 U.S. 677, 686 (1973) (plurality opinion). 
and immutable characteristics. The accidental, unchangeable character of the classifying criteria adds nothing to the argument.

I am not at all certain, however, that this analysis fully disposes of the issue. Although a court could not consistently maintain the position that classification by involuntary characteristics is constitutionally impermissible, or even suspect, the use of such criteria in many situations does seem to violate some shared sense of fairness. There are two ways to account for these seemingly discordant conclusions. First, it may be that in the latter situations-of which the illustrations given earlier may be taken as representative ${ }^{46}-$ something other than the adventitious and immutable nature of the criteria employed underlies the conclusion that they are objectionable. The fact that the characteristic used in classifying people is adventitious and immutable would, if such an argument could be established, be irrelevant in determining whether the classification is permissible. An alternative analysis would start with the proposition that the involuntary nature of a criterion of classification counts against its legitimacy, but then recognize that there are other values to be taken into account that may at times require the use of such a criterion. ${ }^{47}$ An examination of these alternative analyses will help illuminate the issues posed by minority preferences.

Hostility to the use of involuntary characteristics to classify people may have a subtle historical explanation. Classification by such characteristics has frequently been used to perpetuate the dominant political, economic, or social position of certain groups. It thus seems reasonable to suppose that attitudes toward the use of involuntary characteristics have been colored by the fact that their use has often been at war with the egalitarian ideals that have dominated the modern age. ${ }^{48}$ The influence of egalitarian ideals upon our attitudes toward sorting people on the basis of adventi-

${ }^{4}$ See text and notes at notes $40-41$ supra.

${ }^{47}$ Although the latter analysis resembles the argument that classification by adventitious, immutable characteristics is constitutionally suspect, there are significant differences between the two analyses. The purpose of the "suspect classification" doctrine is to require a high degree of justification for classifications held to be "suspect" and to impose upon the courts the obligation of determining whether that justification has been established. The analysis set forth in the text, however, indicates neither how to weigh values nor who should perform the balancing.

48 "Egalitarian" is used here in the broadest possible sense as an expression of the view that all persons are of equal dignity and worth. It thus encompasses the liberal ideals of "equality before the law" and "equality of opportunity" as well as various leveling theories which under some circumstances may be in cornpetition with them. For a survey of the competing theories, see Lakoff, Equality in Political PhILosophy (1964). 
tious circumstances is suggested also by the toleration for-perhaps insistence upon-such a sorting criterion when egalitarian ideals are served thereby. When life itself is at stake, for example, the fundamental equality of all humans-their equal dignity and worth-has at times seemed to require that the choice of who shall live and who shall die be left to chance. "In no other way," as the court reasoned in United States $v$. Holmes, the famous lifeboat case, "are those having equal rights put upon an equal footing . . ..."49

Now whatever other objections there may be to the preferences that recently have been accorded racial and ethnic minorities, it is obvious that those preferences do not serve to maintain a position of dominance for the preferred groups. Not only are the groups given preferential treatment among the least advantaged in the society in terms of political, economic and social status, but it is precisely their disadvantaged status that has provided the primary rationale for preferential treatment. An important reason for the suspicion with which classification by involuntary personal characteristics is viewed is therefore inapplicable when preference is given to racial and ethnic minorities.

Yet the objection to classification by involuntary characteristics does not seem to rest solely upon the use of such criteria to serve nonegalitarian objectives. Legislation that excluded left-handed children from kindergarten would, if unsupported by further justification, undoubtedly be universally condemned as unjust and invalidated by the Supreme Court as a denial of equal protection ${ }^{50}$ even

11 26 Fed. Cas. 360,367 (No. 15,383) (C.C.E.D. Pa. 1842). But cf. The Queen v. Dudley and Stephens, 14 Q.B.D. 273, 285-88 (1884). The selection criterion in these situations is not, of course, a personal characteristic, but that does not appear to be a significant difference. In any situation in which selection by lottery would be acceptable, classification by an adventitious characteristic ought to be equally acceptable if the latter is randomly distributed over the entire population. Illustratively, assume that a life-saving drug temporarily in short supply can be made available only to 20 percent of the persons whose medical needs require it. If a lottery is acceptable as a means of selection, it ought also to be acceptable to employ instead an adventitious characteristic (say, left-handedness) which occurs in 20 percent of the population if it is uncorrelated with race, sex, wealth, political power or any other personal characteristic of social significance. The major argument for using a lottery, rather than a personal characteristic, is that the selection of a personal characteristic may be influenced by knowledge of the characteristics of particular individuals. But this merely emphasizes that we wish to assure chance selection, not avoid it.

Another plausible argument supporting a lottery is that use of a personal characteristic to classify, especially if it is used repeatedly over long periods, may create new class divisions in the society, thereby frustrating the original egalitarian objective. That danger, however, is not uniquely associated with the use of involuntary characteristics, although it is possible that the danger is greater when such criteria are employed.

so The legislation cannot be justifiably invalidated on the ground that left-handedness is irrelevant to the legislative purpose in establishing kindergartens. The legislative purpose 
though the classification neither perpetuated nor created long-term class consequences. The objection to such legislation would, I think, proceed somewhat along the following lines: one goal of a good society is to enlarge the opportunities of individuals to cultivate and express their individuality, to facilitate each individual's opportunity to pursue a personal conception of the good life. It is the goal to which Jefferson referred when he wrote that "Governments are instituted among men" to secure their right to "the pursuit of Happiness." Distribution of opportunities on the basis of involuntary characteristics is incompatible with that goal because the claim of each person to pursue his conception of the good life ought to be given similar consideration. ${ }^{51}$ Perhaps individuals who make a greater effort ought to receive greater consideration, but the fact that one individual differs from another by reason of race, sex, height, or another involuntary characteristic seems an insufficient reason for regarding him as more or less worthy of consideration. If opportunities are in short supply, it might thus be argued, they ought to be rationed on a basis that bears some relationship to the goal of enhancing the ability of individuals to develop their individuality. So, for example, if there are fewer vacancies in universities than applicants for admission, preference might be given to those applicants whose objectives would best be served by a university education or to those whose past efforts revealed a more intense desire to be educated. Chance would thus be eliminated and opportunities awarded on a basis which accords with desert.

The obvious response to this argument is that there is no apparent means of making the judgments called for by such criteria. No calculus exists for determining whether one person's or another's objectives would be better served by access to higher education. Nor are there adequate measures of relative intensity of desire or means by which to determine the extent to which differences in past performance are attributable to effort or to factors, such as native endowment, that are beyond individual control. Measurement is not the only difficulty, moreover. The relationship between adventitious characteristics and individual choice is uncertain. Past effort may be no more than a product of adventitious circumstances, a consequence not merely (and perhaps not at all) of individual will

in this instance would not be to prepare children for school, but to prepare right-handed children. An extrinsic material principle must be introduced to account for the conclusion that exclusion of left-handed children is impermissible. See text and notes at notes 15-24 supra.

si Cf. W. Frankena, Some Beliefs About Justice, The Lindley Lecture, Univ. of KanSas, Department of Philosophy Pamphlet 10, 14-20 (1966). 
but of the family in which one chanced to be born and of natural endowment which offered promise that effort would be worthwhile. ${ }^{52}$ The same may be true of desire.

Thus, the same reasons offered to justify the conclusion that minority preferences are unjust may also be offered to support a conclusion that it would be equally unjust to admit to universities those applicants displaced by the minority preference: though race and ethnicity are adventitious, and hence irrelevant to desert, the same is true of natural endowment and childhood environment, important determinants of success on admission tests and in prior academic pursuits. If use of the former is to be viewed with suspicion because they ignore desert, it is not obvious why use of the latter ought not to be viewed with similar suspicion.

Pushed to the extreme, this line of reasoning threatens the premise with which we began. If individuals are solely a product of forces beyond their control, it is meaningless to posit as a social goal the enlargement of opportunities for them to develop their individuality. All individual goals, desires and efforts would be adventitious from the perspective of the unwitting individual. The determinism that underlies this view has, no doubt, played an important role in shaping modern attitudes, but it is certain that, in its extreme form, it does not command a consensus among Americans. Our legal system and political institutions, our moral conceptions and even the language we speak, reflect a belief that individuals make choices, that human will is a reality. Without that belief, as we are recurrently reminded, our ideals of freedom and human dignity cannot endure. ${ }^{53}$ Perhaps, as Sir Isaiah Berlin has written:

[I]t is a good thing that we should be reminded by social scientists that human choice is a good deal more limited than we used to suppose; that the evidence at our disposal shows that many of the acts too often assumed to be in the individual's control are not so . . . . ${ }^{54}$

Increased awareness of the limits of human choice "has led to . . . exceedingly civilized consequences, and checked much traditional cruelty and injustice."55 The existence of a domain of choice is, nevertheless, the working assumption of our morality and institutions. If that assumption has at times led to cruelty and injustice,

\footnotetext{
${ }^{52}$ See J. Rawls, supra note 41, at 310-12.

53 See, e.g., B. Skinner, Beyond Freedom and Dignity (1971).

st I. BERLIN, supra note 42 , at 73.

55 Id. at 68 .
} 
its abandonment seems likely to be even more pernicious.

If choice is possible, if human actions are not always determined by forces beyond individual control, it is meaningful to refer to a class of characteristics-race, height, sex, illegitimacy and the like-that are undeniably adventitious and immutable from the perspective of the individual. The differential distribution of opportunities on the basis of such characteristics offends a commonly held sense of justice because individuals who differ only in these respects are not differently situated with reference to the social goal of enlarging the ability of individuals to pursue a personal conception of the good life. Only those differences over which individuals have some control are relevant to that goal. The principle that classification by involuntary characteristics counts against the validity of a classification thus rests upon values that are central to our conception of the good society and therefore of the proper role of government.

All that has been established, however, is that the use of such criteria ought to count against the validity of a classification,,$^{56}$ not that they are always impermissible. There are numerous situations in which other values may call for discrimination by involuntary characteristics. ${ }^{57}$ At times, for example, the reward of desert is sacri-

${ }^{56}$ The principle seems sufficient, nevertheless, to explain a decision such as Weber $v$. Aetna Casualty \& Surety Co., 406 U.S. 164 (1972), in which the Court invalidated the provisions of a workmen's compensation statute that discriminated against illegitimate children. The interests served by the classificatory scheme seem insufficient to overcome the values expressed by the principle if the latter are to be accorded any weight at all.

57 Among the situations in which individuals are classified according to involuntary characteristics are those in which special consideration is given the handicapped. See text at note 44 supra. In this case humanitarian values seem to outweigh the principle that classification by involuntary characteristics should be avoided. Special consideration for the handicapped may be viewed, however, as entirely compatible with the values that justify that principle. An initial premise of the argument in support of the principle is that, except for differences of desert, all persons are entitled to equal consideration of their claims to pursue their own conception of the good life. One might argue that "equal consideration" does not mean that equivalent resources must be devoted to all persons, but that some proportionate contribution must be made to enable each individual to pursue his conception with an equal chance of success. See W. Frankena, supra note 51, at 14-15.

A similar argument is sometimes advanced in support of minority preferences: because of their disadvantages, minority group members must receive special consideration if a proportionate contribution is to be made to enhance their opportunities to develop themselves. See, e.g., the arguments summarized in Redish, Preferential Law School Admissions and the Equal Protection Clause: An Analysis of the Competing Arguments, 22 U.C.L.A.L. Rev. 343, 379 (1974). The argument fails because not all members of minority groups are at a greater disadvantage than all whites. See text and notes at notes 109-116 infra. If the goal is to overcome "educational disadvantage," resulting from an applicant's family background or prior education, many white students are certain to have as strong a claim as any member of a racial or ethnic minority. And many members of minority groups, including some who offer 
ficed to a social interest in the meritorious performance of certain tasks. Membership on the University of Michigan basketball team is not equally open to all. The men who have achieved it have, no doubt, demonstrated desire and effort. But no amount of desire and effort would yield a place on the team to the many individuials who lack the necessary physical attributes. We may regret the inability of the latter to fulfill their ambitions, even lament that "life is unfair," ${ }_{58}$ but the fact remains that we prize the ability to play basketball well more highly than the effort and desire to do so.

Now what is true of the University of Michigan's basketball team is also true of its law school, as it is of other law schools and of selective admission higher education programs generally. Traditional academic admissions criteria do not ignore desert-no applicant who lacks desire or who has failed to make a substantial effort is likely to meet the standards of admission-but they undoubtedly exclude many who could not satisfy those criteria with any degree of effort. Desert is thus sacrificed to a conception of social utility, the perception of a social need for highly competent lawyers and other professionals. ${ }^{59}$ If considerations of utility are sufficient to overcome reservations about the use of involuntary characteristics when competence is at stake, there is no apparent reason why similar considerations ought not to prevail in support of minority admission preferences. Unless race and ethnicity are required (for some still unexplained reason) to be treated differently from other involuntary characteristics, ${ }^{60}$ the only question is whether social

the greatest promise of success, would have to be denied preferential treatment. See text and notes at notes 115-16 infra.

5* The "unfairness," of course, is not a product of nature, but of human choice, in this instance the decision to prefer talent to effort and desire. There is nothing inevitable about that decision, and at times we make a different choice, as in the "little leagues" that require that equal playing time be allotted to each child who regularly attends practice sessions.

59 The implicit assumption is that the best index of future professional competence is the quality of performance in the preparatory academic program and that the best index of future success in the academic program is performance on admissions tests and in prior academic programs. Although many educators are uneasy about these assumptions, there is no reason to suppose that the assumptions operate to the special disadvantage of those racial and ethnic minorities that currently benefit from special admissions programs. The potential invalidity of the assumptions does not, therefore, justify preferential treatment of the members of those groups. In any event, the meager available evidence suggests, contrary to the initial assumptions of some proponents of racial preferences, that the standard predictors of law school performance are at least as accurate for blacks as for whites, and perhaps more so. See Schrader \& Pitcher, Predicting Law School Grades for Black American Law Students (Educational Testing Service Rept., 1973).

${ }^{60}$ Competence is not the only value that justifies classification on the basis of involuntary characteristics. In San Antonio Ind. School Dist. v. Rodriguez, 411 U.S. 1 (1973), for example, the Court sustained the validity of school finance systems that distribute educa- 
utility is served by minority preferences.

To the extent social utility is served, race and ethnicity may even be seen as measures of competence. ${ }^{61}$ Competence is the ability to perform a task in line with certain objectives. Those objectives, in the case of educational institutions, are typically defined with reference to some perception of social needs. Traditional academic admissions criteria reflect a particular perception of those needs-a need for students who will provide intellectual stimulation for other students, for lawyers with a high degree of analytic capacity, for physicians with an understanding of biochemistry, and the like. Undoubtedly, these intellectual needs are of critical importance and we depreciate them only at our peril. But they are not the only needs of the society, as educational institutions have occasionally recognized by tempering intellectual standards for admission with the use of geographic preferences. In the same way, special minority admissions programs may serve particular social needs.

It is sometimes argued that even if social utility is served by such programs, they must nonetheless be held invalid because they impose upon the white applicants who would otherwise have been admitted too much of the cost that must be incurred to improve the conditions of minority groups. ${ }^{82}$ The fallacy of that argument should now be apparent. The burden upon the excluded applicant is real, ${ }^{63}$ but it is not different from the burden borne by applicants excluded under traditional criteria. Moreover, it is imposed for precisely the same reason, a judgment that the public welfare will be better served by the admission of someone else. In that respect racial and ethnic admissions criteria do not differ from traditional criteria that are unquestionably constitutional.

The principle that government may not distribute burdens and benefits on racial grounds cannot, therefore, be derived from a more general rule that classification by involuntary characteristics is either invalid or constitutionally suspect. Unless discrimination on grounds of race and ethnicity is independently prohibited by the Constitution, the validity of preferential admission standards for minorities depends only upon a judgment that the public welfare is

tional funds unevenly among students on the basis of characteristics over which they lack control. The decision resulted, in part, from the Court's willingness to give substantial weight to the social value of decentralized decision-making.

${ }^{61}$ See Karst \& Horowitz, Affirmative Action and Equal Protection, 60 VA. L. REv. 955, 961-63 (1974).

${ }^{62}$ See, e.g., Redish, supra note 57, at 388-89; Cohen, supra note 33 , at 141.

63 Thus, there is no reason to question his standing to challenge the validity of racial standards for admissions. But cf. Warth v. Seldin, 95 S. Ct. 2197 (1975). 
served thereby. A final argument in support of the principle that racial and ethnic classifications are prohibited by the Constitution needs to be considered before examining the arguments that can be advanced in support of such a judgment.

\section{Discrimination Against Minorities: The Question of Consistency}

A constitutional principle that government may not distribute burdens or benefits on racial or ethnic grounds is required neither by the "intentions of the framers" nor by a more general principle of constitutional law. Adoption of the principle would be required therefore only if the principle were necessary to justify one or several more particular decisions that the Court would feel compelled to make. ${ }^{64}$ So, for example, if it could be shown that a constitutional rule prohibiting classification on racial or ethnic grounds was necessary to support the line of decisions invalidating legislation that employs racial classifications to the disadvantage of blacks ${ }^{65}$ adoption of the principle would be required. ${ }^{86}$ Posner's argument in support of the principle he proposes is cast largely in such terms. $\mathrm{He}$ urges repeatedly that the same reasons often advanced in support of minority preferences might also be put forth to justify discrimination against a racial or ethnic minority. ${ }^{67}$ Such a defense of the "color-blind" principle, if it could be established, would be not merely persuasive, but compelling. Consistency is not simply a matter of intellectual elegance as some students of the legal system appear to assume, ${ }^{68}$ but rather the critical test of whether decisions serve a coherent set of values.

To justify Posner's principle in this way, however, it is not sufficient merely to show that some of the reasons advanced in support of minority preferences are incompatible with decisons prohibiting discrimination against minorities. It must be shown, rather, that some necessary ground for upholding minority prefer(1972).

"See generally Feinberg, Justice, Fairness and Rationality, 81 YALE L.J. 1004, 1018-21

c5 See, e.g., Hunter v. Erickson, 393 U.S. 385 (1969); Brown v. Board of Education, 347 U.S. 483 (1954); Buchanan v. Warley, 245 U.S. 60 (1917); Strauder v. West Virginia, 100 U.S. $303(1880)$.

" Of course, another possibility is to overrule the earlier decisions. The commitment to the decisions cited supra in note 65 is sufficiently great, however, that they must be deemed a fixed starting point for any further analysis.

"Posner, supra note 2, at 12.

" See, e.g., Arnold, Professor Hart's Theology, 73 Harv. L. Rev. 1298 (1960); Wright, Professor Bickel, The Scholarly Tradition, and the Supreme Court, 84 HARv. L. REv. 769, 77583 (1971). 
ences conflicts with some necessary ground for invalidating discrimination against minorities. Posner does not contend, however, that these different uses of racial and ethnic classifications are wholly indistinguishable; indeed, he acknowledges that "discrimination against whites" is not "the same phenomenon as the sorts of discrimination involved in previous equal-protection cases involving members of racial or ethnic minorities . . . " 69 The concession seems unavoidable, if for no other reason than because of the different social consequences of the current programs of minority preference and the discriminatory legislation that the Supreme Court has previously invalidated. The latter, to suggest only one such difference, served to perpetuate the dominant status of a preferred group -in the case of Southern race legislation, to maintain a virtual caste system-in a manner wholly incompatible with the nation's evolving egalitarian ideals. Minority preferences plainly are not subject to criticism on that ground..$^{70}$

Although Posner does not explicitly consider this distinction between the different uses of racial and ethnic classifications, the response he would make to it seems clear: whether or not the distinction has substance, the Supreme Court is not entitled to consider it in applying the equal protection clause. A rule of constitutional law, Posner contends, must be "sufficiently precise and objective to limit a judge's exercise of personal whim and preference." 71 A rule that requires an assessment of the consequences of discrimination in order to determine whether the discrimination is constitutionally permissible would, he argues, lack the necessary "precision and objectivity" and thus be no more than "a directive that the judges uphold those forms of racial and ethnic discrimination which accord with their personal values."72 Posner's argument thus rests, crucially, not upon a claim that there is no difference between current programs of minority preference in higher education and earlier legislation discriminating against minorities, but upon a conception of the judicial function that requires the courts to ignore differences that do exist.

Posner's argument addresses an important problem. The purely personal preferences of judges, all would concede, are not adequate

69 Posner, supra note 2 , at 20.

${ }^{70}$ See text and notes at notes $48-49$ supra. There are, as discussed below, additional grounds for distinguishing between current minority preferences and earlier legislation discriminating against racial minorities. See text and notes at notes 81-86 infra.

71 Posner, supra note 2 , at 22.

72 Id. at 25. 
reasons for judicial limitation of legislative power. Something else is required. Yet Professor Bickel's assessment of the judicial career of Mr. Justice Frankfurter serves equally well as a summary of nearly two centuries of experience with judicial review:

... he never successfully identified sources from which this [constitutional] judgment was to be drawn that would securely limit as well as nourish it, he never achieved a rigorous general accord between judicial supremacy and democratic theory. ${ }^{73}$

The problem of identifying sources that will "limit as well as nourish" judgment is especially acute in fashioning law under the equal protection clause because, as developed earlier, the clause does not reveal the values courts are to defend against legislative incursion..$^{74}$ Absent a consensus concerning the appropriate sources of judgment, there is an inevitable risk that judgment will turn upon the personal preferences of the judges.

Precisely because that risk is unavoidable, however, its existence cannot be used as Posner attempts to use it, as a justification for selecting one rather than another material principle for giving meaning to the equal protection clause. Value choices necessarily underlie the selection of one or another principle, and, absent societal agreement upon either the values or the source from which they are to be derived, there is no escape from the risk that the principle selected will reflect values personal to the judge. The principle Posner would have the Court adopt is, thus, neither more nor less "objective" than a principle which would sanction minority preferences.

Posner himself comes close to recognizing this problem when he considers the question whether the principle he proposes "is itself subjective and arbitrary, because it does not explain why only race and ethnic origin, and not all immutable or involuntary characteristics"75 are to be held impermissible bases of classification. His response to that question is instructive. "There are," he writes, "two grounds of distinction:

The first is one of necessity: if the constitutional principle were defined in terms of all involuntary characteristics, it would violate the requirement that a constitutional principle bind the

\footnotetext{
33 A. Bickel, The Supreme Court and the Idea of Progress 34 (1970).

"See text and notes at notes 6-12 supra.

${ }^{25}$ Posner, supra note 2, at 23.
} 
judges. Since no one could argue that no involuntary characteristic should ever be used as a criterion of public regulation, the principle would give the judges interpreting it carte blanche to pick and choose among groups defined in accordance with one of the involuntary characteristics. Second, the grouping of people by an ancestral characteristic is surely not the same phenomenon as, say, grouping by sex or age. A rule forbidding blacks to work in mines, one forbidding women to work in mines, and one forbidding children to work in mines, may all be discriminatory, but one must strain to regard them as identical, in the sense that if one is invalid, so, obviously, are the others. ${ }^{76}$

Neither reason is persuasive.

The second point merely calls upon our intuition that race, sex, and age differ from one another. Brief reflection will reveal, however, that whether or not they do depends upon the context in which the question arises. Race and sex differ from age in that neither of the former, in contemporary America, would be thought a permissible basis for differentiating among persons in determining the right to vote or in formulating compulsory school attendance laws. Race differs from sex and age, however, when the issue is liability to compulsory military service: the latter, but not the former, would generally be considered appropriate bases for classification. ${ }^{77}$ None of these characteristics would be thought a permissible basis for determining liability to the thumbscrew: all persons would be equally exempt because their common characteristics, for this purpose, would be deemed more significant than their differences. Context, thus, is of critical importance in determining the validity of these criteria of classification. The reason for its importance is that the consequences of employing one or another of the criteria differ in different contexts, and it is by an appraisal of these consequences that we determine whether the criteria are permissible bases for sorting people.

Posner's first distinction implicitly rests upon just such an appraisal of consequences. His conclusion that a court could not consistently apply the principle that "no involuntary characteristic should ever be used as a criterion of public regulation" appears to rest upon a judgment that in some situations the prohibition of such a criterion would lead to undesirable consequences. ${ }^{78}$ His proposal

78 Id. at 23-24.

${ }^{77}$ As these illustrations demonstrate, society's views concerning the permissible bases of classification in various contexts are not static; cf. U.S. CoNST. amend. XXVII (proposed).

${ }^{78}$ See text and notes at notes 43-45 supra. 
that the equal protection clause be read to embody an unbending rule of "color-blindness," on the other hand, seemingly reflects a judgment that a prohibition of the use of racial and ethnic critera would not produce undesirable consequences. Now these judgments may or may not be correct. Posner's apparent recourse to them, however, is incompatible with his argument that the "color-blind" principle is required because a rule permitting courts to consider the consequences of racial and ethnic discrimination would be merely "a directive that the judges uphold those forms of racial and ethnic discrimination which accord with their personal values." 79 Unless there exists some reason other than a differential appraisal of consequences for distinguishing between race, ethnicity, and other involuntary characteristics-a reason Posner does not suggest-a rule that prohibits use of the former but not the latter is, on Posner's argument, no more than "a directive that the judges uphold those forms of [discrimination on the basis of involuntary characteristics] which accord with their personal values." 80

Posner's effort to divorce constitutional principle from an appraisal of consequences not only deprives the "color-blind" principle of its last claim to reasoned support, it ignores the fact that the strong intuitive appeal of that principle is grounded in particular historical circumstances. The idea that racial classifications are wholly forbidden by the Constitution apparently took root in the mid-1950s, in the effort to explain a series of per curiam decisions that extended the rule of the School Segregation Cases ${ }^{81}$ to all public facilities. ${ }^{82}$ Other principles that would justify those decisions were, no doubt, imaginable, but in the absence of any explanation by the Court, a principle requiring government to be "color-blind," as urged long ago by the first Justice Harlan, ${ }^{83}$ was both plausible and attractive. ${ }^{84}$

" Posner, supra note 2, at 25.

so It might be argued that even though courts are free to consider consequences in fashioning a constitutional rule, any rule so fashioned must not leave room for judicial appraisal of consequences. Although this argument would justify the distinction Posner draws between race, ethnicity, and other involuntary characteristics, it would also-contrary to his argument-justify the principle that government must be "color-blind" except where racial classifications give a preference to designated racial and ethnic groups.

*1 347 U.S. 483 (1954).

s2 See, e.g., Gayle v. Browder, 352 U.S. 906 (1956); Holmes v. City of Atlanta, 350 U.S. 879 (1955); Mayor \& City of Baltimore v. Dawson, 350 U.S. 877 (1955).

${ }^{3}$ Plessy v. Ferguson, 163 U.S. 537, 559 (1896).

* The Court's opinion in the School Segregation Cases rested heavily on the importance of public education in the United States and the harm sustained by black children required to attend lawfully segregated schools. "We conclude that in the field of public education the doctrine of 'separate but equal' has no place. Separate educational facilities are inherently 
A large measure of the attractiveness of the principle lay in its responsiveness to the belief that the dignity and worth of individuals are unaffected by accidents of birth. "Jim Crow" legislation not only withheld opportunities for the "pursuit of happiness" on grounds wholly incompatible with that belief, it was an integral part of a social milieu which systematically degraded and humiliated people for reasons wholly beyond their control. A principle forbidding government to classify by race would at least keep government out of so dirty a business and, by depriving it of an apparently vital support, perhaps end it altogether. Other values also seemed to be served by the principle. Its adoption appeared to promise significant improvement in the economically depressed condition of the black population, for it would require that governmental benefits, a significant form of wealth in modern society, be equally available to all, in fact as well as in theory. An end to enforced separation of the races offered the additional hope that traditional prejudices would be eliminated as blacks and whites came to know one another as individuals, a prospect viewed by many as desirable not only as a step toward realizing the cultural ideal of the "brotherhood of man," but as a means of further reducing the barriers to the economic and social advancement of the black population. These hopes may now seem naive, but they were nevertheless crucial to the emergence of the idea that government must be "color-blind."

By the early 1960s evidence had begun to accumulate that the values that suggested the principle that government must ignore race were not as harmonious as they had initially appeared. The emergence of the issues of busing to achieve racial balance, benevolent quotas in employment and public housing, community control, and preferential admission standards for colleges and universities signalled a growing belief that government could not simultaneously treat race as irrelevant and achieve either integration or the economic and social advancement of the black population. ${ }^{85}$ Goals which had earlier appeared consistent, even mutually reinforcing, began to appear to be in conflict.

unequal." 347 U.S. 483,495 (1954). Since the Court's articulated rationale did not extend to other public facilities, those who sought to comprehend subsequent decisions invalidating state-imposed segregation of these facilities needed another explanation-a principle broad enough to cover all public facilities, not merely schools. The Court's current doctrine, that a law that classifies persons on the basis of race is "suspect," was not articulated until 1964. McLaughlin v. Florida, 379 U.S. 187, 196 (1964).

85 See, e.g., Bittker, The Case of the Checkerboard Ordinance: An Experiment in Race Relations, 71 YALE L.J. 1387 (1962); Kaplan, Equal Justice in an Unequal World: Equality for the Negro-The Problem of Special Treatment, 61 Nw. U.L. Rev. 363 (1966); Kirp, Community Control, Public Policy, and the Limits of Law, $68 \mathrm{MrcH}$. L. Rev. 1355 (1970). 
To argue that constitutional principles must be formulated without regard to such goals ignores the fact that it is precisely the consideration of those goals that suggested the "color-blind" principle. The altered perception of social reality over the past two decades-and the consequent need to reconsider the priority among our goals-is, indeed, a classic illustration of Perelman's observation that "[a]ny moral, political, or social evolution leading to a modification in the scale of values will at the same time modify the characteristics regarded as essential for the application of [the principle of similar treatment for those similarly situated]." ${ }^{86}$ It is one thing to maintain that people are similarly situated, notwithstanding racial differences, when the consequence of doing so appears to be the alleviation of suffering and the establishment of an integrated society. It is quite another to do so when the consequence appears to be precisely the opposite.

Professor Posner is right to point out, however, that there are dangers associated with a principle that would permit race and ethnicity to be considered if the anticipated consequences seem desirable. "The necessary inquiries," he writes, "are intractable and would leave the field open to slippery conjecture." ${ }^{87}$ If this overstates the matter somewhat, the point is nonetheless important. Judicial freedom to examine the consequences of a racial or ethnic classification in determining its validity may also yield judgments disadvantageous to minorities. The risk is unavoidable. Yet it is difficult to understand Posner's conclusion that the "antidiscrimination principle is . . . more compelling when it is divorced from empirical inquiries into the effects of particular forms of discrimination on the affected groups." 88 Unless it is supported by an appraisal of such effects, an antidiscrimination principle is not even persuasive, let alone compelling. It is not, as we have seen, required by history, nor can it be derived from a more general principle of constitutional law. Whence, then, does it come? ? $^{9}$

see text and note at note 26 supra.

${ }^{\mathrm{n} 7}$ Posner, supra note 2, at 24.

ss Id.

* We deceive ourselves, moreover, if we believe that decisions invalidating legislation that discriminates against blacks or other minorities can be insulated from reexamination by adopting a constitutional rule that unqualifiedly prohibits racial and ethnic discrimination. If the preponderant sentiment of the society should ever conclude that some such legislation is desirable, it can be safely asserted that, insofar as they seem to stand in the way, those decisions will be overruled, if not all at once then gradually, if not openly then silently. An inflexible rule prohibiting discrimination on racial or ethnic grounds might, conceivably, retard such a development, but that judgment seems hardly less conjectural than those that are required in appraising the consequences of legislation that employs racial 


\section{The Argument for a Minority Preference IN LAw School ADMissions}

A decision whether legislation treats differently individuals who must be deemed similarly situated for constitutional purposes and thereby denies "the equal protection of the laws," requires a prediction and appraisal of the likely consequences of the legislation. Legislation that employs racial or ethnic criteria is not subject to a special constitutional rule. Its validity depends upon a judgment about whether it will lead us toward or away from the kind of society we want.

These are not only the conclusions that emerge from the preceding analysis, they are also the clear teaching of Swann $v$. CharlotteMecklenburg Board of Education..$^{90}$ Legislation that classifies children by race to maintain racially segregated schools is impermissible. But classification by race is "within the broad discretionary powers of school authorities" if "in order to prepare students to live in a pluralistic society" those authorities wish to adopt a policy "that each school should have a prescribed ratio of Negro to white students reflecting the proportion for the district as a whole." ${ }^{11}$ The difference is not in the criteria employed to classify students, but in the Court's evaluation of the consequences of the two programs. The one leads to a racially segregated society, with all that that entails for the welfare of the black population; the other offers hope of a racially integrated society and of a time when at least one adventitious circumstance will have been removed as a barrier to the "pursuit of happiness."

The validity of preferential admissions policies in institutions of higher learning, similarly, turns upon a judgment about whether the policies will contribute to or retard development of the kind of society we want. The competing considerations have been so thoroughly canvassed in the literature ${ }^{92}$ that it would be pointless to

or ethnic criteria. See note 130 infra.

so 402 U.S. 1 (1971).

91 Id. at 16. The quoted language is only dictum, but it seems to be a deliberate statement of the Court's views and, therefore, dictum of substantial weight. Significantly, in approving a racial classification for the purpose of achieving integration, the Court said nothing about the "suspect" quality of racial classifications.

The attempt to distinguish preferential admissions programs from the policy approved in Swann on the grounds that the latter neither imposes costs on whites nor discriminates between blacks and whites is effectively refuted in Ely, supra note 2, at 724-25.

92 In addition to the articles cited elsewhere, see Graglia, Special Admission of the "Culturally Deprived" to Law School, 119 U. PA. L. Rev. 351 (1970); O'Neill, Preferential Admissions: Equalizing the Access of Minority Groups to Higher Education, 80 YALE L.J. 699 (1971); Symposium-De Funis: The Road Not Taken, 60 VA. L. Rev. 917 (1974); 
state them at length. Instead, I want to develop briefly the reasons that seem to me most persuasively to support preferential admissions policies, primarily for the purpose of considering the arguments that may be advanced against those reasons. ${ }^{93}$

Any justification of racial and ethnic preferences must begin by recognizing that race and ethnicity are socially significant characteristics. Many Americans, and especially those who are members of the groups that have been the beneficiaries of preferential admissions practices, live in communities and belong to organizations that are defined in racial and ethnic terms. The direction of their loyalties and of their sympathies is significantly determined by their racial and ethnic identifications. Whether, or to what extent, that is desirable is currently the subject of much debate; but whether it is good or bad, it is a reality with which the law must contend. It is not a matter of social indifference, for example, that the 12 percent of those Americans whose incomes fall below the "low income level" are not randomly distributed among the various racial and ethnic groups but are disproportionately the members of a few racial and ethnic minorities. ${ }^{94}$ This concentration of poverty has important consequences in its impact upon individuals and in the prospects for social stability..$^{95}$ Race and ethnicity are not, in other words, superfi-

Symposium-Disadvantaged Students and Legal Education-Programs for Affirmative Action, 1970 ToL. L. REv. 277. These articles refer to much additional literature.

23 The discussion that follows is cast largely in terms of law school admissions. With the change of an occasional word or phrase, however, virtually all that is said is equally applicable to other parts of the university. Although there are relevant differences between law schools and other departments, it is almost inconceivable that different constitutional rules will be developed for other parts of the university.

" Bureau of the Census, Statistical Abstract of the United States 389, 394 (1975) (Tables 631,642 ). Income is not the only measure of well-being but it serves tolerably well as a single indicator since other social indicators do not reveal a different pattern. Thus, mortality rates at every age are strikingly higher for blacks than for whites, $i d$. at 59 (Table 82); and educational attainment, as measured by schooling, is significantly lower for blacks and persons of Spanish origin than for whites (including ethnic sub-groups within the white population), id., at $34,116-17$ (Tables $41,186-90$ ).

"s Posner argues that the interest in social stability is not a permissible justification for minority preferences. Posner, supra note 2 , at $26-31$. In doing so, however, he blurs a critical distinction. Starting with the premise that the risk of social instability is "never a legitimate ground for refusing to apply a constitutional principle," he concludes that that risk is not "entitled to weight in a constitutional analysis. . . I" Id. at 30 . But these are very different propositions. If there were a constitutional principle prohibiting classification by race and ethnic origin, minority preferences could not be justified even though they were thought necessary to the maintenance of social peace. But there is no such constitutional principle, nor is there any basis for concluding that such a principle is required by constitutional traditions. The question is whether such a principle ought to be adopted by the Supreme Court. It is inconceivable that the Court should ignore the interest in social stability in answering this question. 
cial aspects of "deeper" social problems such as poverty or inadequate education, but are integral to those problems.

In these circumstances, the question whether blacks and other racial and ethnic minorities are substantially represented in law school classes and at the bar assumes considerable importance. Gross underrepresentation of these groups has consequences quite different from those that would result from, say, the gross underrepresentation of men with one blue and one green eye or of lefthanded women. Individuals who share these latter characteristics do not identify with one another. Their associations are not significantly determined by their common trait. They do not share a distinctive cultural background which may make it easier for them to communicate with one another than with others. Governmental decisions do not affect them differently than they affect other persons, and, conversely, their views on issues of public policy are likely to be distributed in the same way as in the general population. In all these respects, individuals defined by these characteristics differ from the members of racial and ethnic minorities. And it is precisely because of these differences that gross underrepresentation of the latter in law school and the bar poses a significant social problem.

Consider first the educational responsibility of the law schools. One of the objectives is to assist students in acquiring an understanding of the environment within which legal decisions are made. It has been a familiar idea at least since the time of Plato that those who govern need an understanding of the governed. The need is common to all forms of government, but in a democracy it is critical. Now lawyers in our society very frequently are cast in the role of "governors," whether as public officials or as community leaders, and in that role require an understanding of the diverse elements which comprise the population. The need for such an understanding is hardly less important to successful performance of the lawyer's role in the representation of private interests, for without it efforts to anticipate and influence official action are a good deal less likely to be fruitful. It is inevitable that this understanding, so far as it can be gained in an academic setting, will be acquired largely from books. To a substantial degree, however, it is also acquired by interaction among students, through exposure to differing points of view

Posner's discussion of this issue blurs another important distinction, the difference between yielding to specific threats of violence and attempting to establish a social order which, because of its responsiveness to the needs of the citizenry, is not likely to generate threats of violence. The former, in all but rarest circumstances, must be considered deplorable, but the latter ought to be considered one of the most important goals of social policy. 
in class discussion and in less formal settings. Diversity in the student body contributes to student understanding of the variety of views which exist in contemporary America and helps develop their ability to develop and defend their own views. The absence of racial and ethnic minorities in law school, or their presence in very small numbers, ${ }^{96}$ may significantly detract from the educational experience of those students who are admitted.

Professor Posner develops at some length an argument that minority preferences cannot be justified by the desirability of a diverse student body. "For a diversity argument to be convincing," he correctly maintains, "it must identify a differentiating factor that is relevant to the educational experience." The only significance of race, he argues, lies in its strong correlation with other characteristics, like poverty, that arguably are relevant to diversity in the educational experience. "Race in this analysis is simply a proxy for a set of other attributes-relevant to the educational process-with which race, itself irrelevant to the educational process, happens to be correlated."97 The use of race as a proxy, Posner argues, may be "efficient" insofar as it reduces the costs of identifying individuals who have characteristics that are relevant to the educational process, but it is objectionable because it rests upon and thus "legitimizes the mode of thought and behavior that underlies most prejudice and bigotry in the United States." ethnicity may be used as a proxy for desirable characteristics with which they are correlated, he concludes, the same interest in efficiency which justifies that use would permit them to be employed as a proxy for undesirable characteristics, thereby justifying discrimination against minorities.

The error of this argument lies in its failure to appreciate the social significance of race, quite apart from its statistical correlation

1 Posner somehow concludes that because the University of Washington Law School set a target of 20 percent minority admissions, a percentage roughly equal to the proportion of the specified minorities in the national population, its program could not have been motivated by a concern for enhancing educational quality through diversification of the student body. Posner, supra note 2, at 8. Posner is right that there is no "rational connection between seeking proportional representation of minorities, on the one hand, and enhancing the quality of the educational experience by providing some representation for members of minority groups who could not gain admission on the basis of academic promise alone, on the other." Id. at $8 \mathrm{n} .18$. It seems clear, nonetheless, that the number of minority students must be substantial to serve effectively the educational objectives of diversity. Since the population percentage figure may have been used as a convenient yardstick for substantiality, it is not clear that Washington was unconcerned with educational quality.

"Id. at 9.

"Id. at 12. 
with other attributes. Precisely because race itself is socially significant, students need knowledge of the attitudes, views and backgrounds of racial minorities. Posner is right to insist, although he overstates the point somewhat, that there "are black people (and Chicanos, Filipinos, etc.) . . . who have the same tastes, manners, experiences, attitudes, and aspirations" as many whites. ${ }^{99}$ What he ignores is that encountering that diversity is an important part of the educational process. Well-intentioned whites, no less than bigots, need to learn that there is not a common "black experience" and to appreciate the error of such statements as "blacks want (believe, need, etc.) . . . ." Moreover, the distribution of attitudes among blacks is not the same as it is among whites. And that too is worth knowing. If the distribution of perceptions and views about politics, or crime, or family is different among blacks than among whites, that in and of itself may have important implications for public policy.

The educational objectives of a minority presence in law school, finally, encompass more than increased understanding of minority groups. There is also a need to increase effective communication across racial and ethnic lines. Many white students, for example, need to learn to to be able to disagree with blacks candidly and without embarrassment. ${ }^{100}$ I cannot imagine that any law teacher whose subject matter requires discussion of racially sensitive issues can have failed to observe the inability of some white students to examine critically arguments by a black, or the difficulty experienced by others in expressing their disagreements with blacks on such issues. Yet, these skills are not only a professional necessity, they are indispensable to the long-term well-being of our society.

Substantial representation of blacks, Chicanos, American Indians, Puerto Ricans (and perhaps other racial and ethnic minorities) in law school student bodies is necessary also because more lawyers are needed from these groups to serve adequately the legal needs of their members. ${ }^{101}$ The standard response to that claim, eloquently

${ }^{99}$ Id. at 8 . The point is overstated because it is hard to imagine a black person who has entirely escaped the experience of being black.

${ }_{100}$ Black students, of course, similarly need to learn to deal with whites, but my concern at this point is with the educational experience of those students who would be in law school without special admission programs.

101 For (dated) estimates of the number of lawyers from these groups see Edwards, $A$ New Role For The Black Law Graduate-A Reality or an Illusion? 69 Mich. L. Rev. 1407, 1432-34 (1971); Gellhorn, The Law Schools and the Negro, 1969 Duke L.J. 1069; Reynoso, La Raza, The Law and the Law Schools, 1970 ToL. L. REv. 809; Strickland, Redeeming Centuries of Dishonor: Legal Education and the American Indian, 1970 ToL. L. REv. 847. 
expressed by Justice Douglas in his DeFunis dissent, is that "[t]he purpose of [a state university] cannot be to produce Black lawyers for Blacks, Polish lawyers for Poles, Jewish lawyers for Jews, Irish lawyers for the Irish. It should be to produce good lawyers for Americans . . . ."102 This is a compelling social and political idea\$. Constitutional law ought not, however, in the single-minded pursuit of that ideal, ignore the existence of other values. Although it would be absurd to suppose that only a Jewish lawyer can adequately represent a Jew or that only a black lawyer can adequately represent a black, it is true nonetheless that many Jews and many blacks (like many persons of other ethnic and racial backgrounds) would prefer to be represented by lawyers with an ethnic and racial identity similar to their own. The satisfaction of these wants, absent strong countervailing reasons, ought to be a permissible goal of public policy. ${ }^{103}$

In a society in which racial and ethnic identities play an important role in everyday life, a lawyer's racial or ethnic background may have an important bearing on his ability to serve his client. Many of the tasks that lawyers perform for their clients require an understanding of the social context in which the client's problem arises. A brilliant and effective tax specialist is, for that reason, unlikely to be an effective representative in a labor negotiation. The reason is not simply that he is unfamiliar with the law of labor relations, it is also and perhaps primarily that he lacks an understanding of the practical problems of labor relations, of the customs that have developed in dealing with those problems, and of the style and manners of collective bargaining. To the extent that racial and ethnic groups form distinctive subcultures within our

102416 U.S. 312,342 (1974).

${ }^{103}$ Similar indulgence should, of course, also be shown for the preferences of whites or Gentiles. As relationships become more personal, the case for individual freedom in these relationships, including freedom to make "irrational" decisions, becomes stronger, a judgment which is reflected in much existing anti-discrimination legislation. See, e.g., 42 U.S.C. $\$ \S 2000$ e(b), 3603(b) (1970).

A conclusion that society can tolerate private discrimination in some settings, e.g., the lawyer-client relationship, does not mean that society should tolerate discrimination in all personal relationships. There is, no doubt, an important personal element in the relationships within the student body, though not so personal as the lawyer-client relationship, but to allow each student to select a school on the basis of racial considerations would, presumably, reintroduce many of the baneful consequences of a segregated school system.

Distinctions such as these no doubt involve nice judgments and, therefore, certain dangers. The goals of social policy are not likely to be furthered, however, by the adoption of constitutional rules that foreclose such judgments entirely. The proper question is not whether such judgments shall be made, but how and by whom. See text and notes at notes $119-46$ infra. 
society, the representation of some of their members in connection with some of their legal needs may involve similar difficulties for the "outsider." The ability to "speak the language" of the client, to understand his perception of his problem, and to deal with others in the community on his behalf are qualities essential to being a "good lawyer." These qualifications are more likely to be found among lawyers who share the client's racial or ethnic identity, at least to the extent that the client's life is bound up in a community defined in these terms. ${ }^{104}$

Admitting a minority group member to law school does not, of course, guarantee that upon graduation he will practice law among the members of his racial or ethnic group. But in light of the patterns of American life, it seems virtually certain that a substantially increased number of minority law graduates will mean a substantial increase in the number who will serve the needs of minority groups. Those who do take advantage of other opportunities ought not to be counted as a social loss. ${ }^{105}$ The integration of blacks and other disadvantaged minorities into the larger economic, political and social framework of the society continues to be an essential social goal. Many of the blacks who join Wall Street law firms, corporate law departments, labor union legal staffs, government agencies, or law faculties, will retain a sense of identification with the black community and maintain ties with it. A black presence is likely to alter the behavior of these institutions in a host of subtle and perhaps not so subtle ways, making them more responsive to the varying needs of the black community. No less significantly, the presence of blacks in these institutions provides evidence to the black community that important centers of American life are open to its members, evidence that may exert a shaping influence upon the aspirations of black children and may aid in the long-term acceptance by blacks of the institutional framework of American society.

These latter considerations point to a final set of reasons for increasing the number of minority law students and lawyers. The special admissions programs which have been undertaken by the law schools must be seen as part of a larger effort by the nation to improve the conditions of life of some of its most disadvantaged

104 Some white and some non-Hispanic people, to be sure, have these qualities to a greater degree than some blacks and some persons of Spanish origin, but there are limits to the precision that can be demanded of social policy. How, for example, are law schools to determine which blacks or which persons of Spanish origin are insufficiently rooted in "the" black or Hispanic communities to serve these purposes?

${ }_{105}$ For a more complete development of this theme, see Edwards, $A$ New Role for The Black Law Graduate-A Reality or an Illusion? 69 Mich. L. Rev. 1407 (1971). 
citizens. In part, that effort involves an attempt to accelerate the growth of a "middle class" within certain racial and ethnic minority groups. The justification for minority preferences within that overall strategy is not difficult to discern: to the extent that racial and ethnic identifications and loyalties continue to be important, there is hope that the strengthening of the black, Chicano, or Puerto Rican middle class through such preferences will have a catalytic effect. Increased numbers of black and Hispanic lawyers and other professionals should encourage the aspirations of black and Hispanic children. ${ }^{106} \mathrm{~A}$ minority presence in the many settings in which societal decisions are made seems likely to produce decisions more responsive to the needs of minority communities. The organizational talent and financial resources of a minority middle class, experience suggests, will to some extent be put at the service of less advantaged members of minority groups. The hope, in short, is to set in motion a chain reaction leading to the break-down of a complex of conditions which today condemn large numbers of people to lives of poverty and desperation.

Substantial representation of minority groups in the student bodies of law schools thus serves a number of important purposes. What must be understood is that if the law schools had adhered to traditional admissions criteria, it would not have been possible to obtain or even approximate the level of representation which has been reached in recent years. ${ }^{107}$ Nor is there any reason to anticipate that those levels could be maintained in the near future under traditional standards. ${ }^{108}$ Opponents of racial and ethnic preferences generally concede this point, but argue that if the goal of increased

IN Posner argues persuasively that the need for role models does not require proportional representation of minorities within a profession but only a large enough number to demonstrate that the profession is open to members of the child's group. Posner's further assertion that the number required for this purpose is unrelated to the size of the minority group is quite wrong. The aspirations of children are influenced not only, and almost certainly not. primarily, by the models provided by the mass media but by adults with whom they come into regular contact. The message that the professions are open to blacks, that a professional career is a realistic aspiration, is less likely to be conveyed by occasional glimpses of a black Supreme Court justice or cabinet officer than by observing a relative who is a lawyer, or a neighbor who is a chemist, or whatever. The chances for observation of this sort are, obviously, directly related to numbers.

207 See aBa Section of Legal Education and Admission to the Bar, Law Schools and Bar Admission Requirements 36 (1975).

${ }^{100}$ See Askin, Eliminating Racial Inequality in a Racist World, 2 Civ. LiB. L. REv. 96, 99-100 (1975); Summers, Preferential Admissions: An Unreal Solution to a Real Problem, 1970 ToL. L. REv. 377, 378. None of the minority students who enrolled at the University of Washington in the 1971 entering class would have been admitted had they been judged on the criteria applied to all others. DeFunis v. Odegaard, 416 U.S. 312, 325 (1974) (Douglas, J., dissenting). 
minority admissions is to be achieved, it must be by some means other than the use of such preferences.

The most frequently advocated alternative ${ }^{109}$ is to reserve a percentage of each class for applicants from disadvantaged backgrounds. ${ }^{110}$ Blacks, American Indians, and persons of Hispanic origins would, it is anticipated, benefit from such a policy because a disproportionate number of them come from such backgrounds, but the policy would extend also to Appalachian whites or anyone else from a disadvantaged background. ${ }^{111}$ The effort would be to identify those applicants who, through perseverance and other qualities, had overcome the handicaps of their backgrounds, though not sufficiently to meet the school's regular admissions standards. Of course, no one knows how large a part of the entering class would have to be reserved for admission on such criteria to obtain minority representation roughly equal to that produced by existing programs. ${ }^{112}$ Clearly, the percentage would have to be considerably greater than that which the law schools currently reserve for preferential minority admissions. ${ }^{113}$

${ }^{109}$ Another possibility would be to select the student body randomly from those applicants with LSAT scores and college GPAs above a minimal level. This proposal is subject to all the objections raised in the text.

${ }^{110}$ See, e.g., Douglas, J., dissenting in DeFunis v. Odegaard, 416 U.S. 312, 338 (1974).

"II The discussion which follows assumes that the proposal is put forth candidly and not in the expectation that covert preferences would be given to certain racial and ethnic groups in the administration of the policy. See Karst \& Horowitz, supra note 61, at 972-74.

112 Because proponents of this position do not specify what kinds of background are to count as "disadvantaged" it is impossible to estimate percentages. Family poverty seems to be what most of the proponents have in mind, but it is not obvious why that characteristic should be singled out. Many affluent children come from homes where the parents are alcoholics, emotionally unstable, or otherwise unable to provide a background conducive to development of a child's educational potential. Many poor children, conversely, come from homes which provide the strongest sort of support for their educational development. An admissions officer would have to determine whether a greater ability to overcome adversity has been shown by the white middle-class suburban child of an alcoholic, wife-beating father or a poor black who grew up in an inner-city ghetto. Should it, for example, count against the latter (as demonstrating that his background was not disadvantaged) that he is the youngest of five children all of whom have earned college degrees?

${ }_{113}$ Of the approximately ten million children who, in 1972, were in families with incomes below the low income level, 57 percent were classified as white and 43 percent as "Negro and other races." Bureau of the Census, Statistical Abstract of the United States 389 (Table 631) (1975). If the definition of a disadvantaged family is extended to include families with an income between 100 percent and 125 percent of the low income level, another four million children are added, three-quarters of whom are white. Id. at 390 (Table 633). Assuming that applicants in this category are randomly distributed between whites and "Negro or other races," the University of Washington would have had to use special admissions criteria not for 15-20 percent of its entering class, as it did, but for 40-50 percent. If, on the other hand, the University were to continue the special admissions program at the 15-20 percent level, minority representation might be expected to decrease to between 5 percent and 7.5 percent of the student body. 
The social cost of reshaping special admissions programs in this way would be very great, involving exclusion from law schools of a substantially larger percentage of the most talented students. That cost alone should be sufficient to prevent such a plan from being considered an acceptable alternative to existing special admission programs. In addition, however, the proposal is not an acceptable alternative because it is incompatible with the objective of achieving a substantial increase in minority enrollment. Existing special admissions programs employ racial and ethnic preferences not only in admissions but also in awarding financial assistance. If the former is to be held unconstitutional, so presumably must the latter. Current minority enrollments at many institutions simply could not be maintained, or even approximated, if financial assistance were to be distributed in a racially neutral manner. At the present time, it is not uncommon for minority students-comprising, say, 10 percent of the student body-to receive 40-50 percent of all financial assistance granted by their schools. ${ }^{114}$ If the number of students from poor families who are admitted is substantially increased by use of racially neutral admission standards for disadvantaged students and if financial assistance is distributed in a racially neutral way, the financial condition of virtually every university makes it certain that substantially less money will be available to aid minority students. The number of minority students would undoubtedly decrease.

Reshaping special admission programs to focus upon disadvantaged applicants, rather than upon minorities, would also force the exclusion of some of the ablest minority applicants. It is reasonable to suppose that a substantial percentage of the (not otherwise admissible) minority applicants who have the best chance of success in law school and the profession come from backgrounds that cannot plausibly be considered disadvantaged.115 Opponents of minority preferences have found it especially galling that the child of a wealthy and well-educated professional should receive preferential treatment simply because of his or her race. But this objection is well-founded only if the preference is seen as an effort to compensate for the disadvantaged background of an individual. If preferences are justifiable because they deal with the problems resulting from the continuing social significance of race and ethnicity, there is nothing unjust in awarding a preference to minority applicants who

II' O'Neil, Racial Preference and Higher Education: The Larger Context, 60 VA. L. REv. 925 n.2 (1974).

115 See note 57 supra. 
come from advantaged backgrounds. The preference is granted for the same reason that preference is shown for exceptionally bright applicants-a judgment that the qualities of the individuals admitted are likely to make them more useful to society than those who are excluded. ${ }^{116}$

Racial and ethnic preferences are, thus, the most-quite possibly, the only-feasible means of achieving substantial representation of certain racial and ethnic groups in law schools. ${ }^{117}$ In light of the important social values that are served by that representation, the argument against racial and ethnic preferences would have to be compelling to justify judicial adoption of a constitutional rule denying government the power to employ them. ${ }^{118}$

${ }^{115}$ See text and notes at notes 57-62 supra; cf., Hughes, Reparations for Blacks? 43 N.Y.U.L. REv. 1063, 1072-73 (1968).

117 Professor Clyde Summers has argued that preferences do not actually increase the number of minority students in law school, but only alter their patterns of enrollment. If the preferences were abandoned, he maintains, minority students who are now preferentially admitted to more selective institutions would be admissible under the normal standards of somewhat less selective institutions. Summers, supra note 108, at 381-84. My impression, from conversations with faculty members at other schools, is that Summers is overly optimistic in predicting the schools for which minority students would qualify if preferential admissions policies were abandoned. A substantial majority of the minority students admitted to the University of Michigan Law School last year, for example, would not have qualified for admission to nearby Wayne State University Law School under standards applicable to its white students.

Knowledge of how far down the ladder minority students would have to go to gain admission to a law school is important for several reasons. First, as Summers recognizes, the more selective schools in general are the schools with the most resources for financial assistance. Second, graduates of schools further down the ladder of prestige have far more restricted job opportunities. See Edwards, supra note 105. Third, any assessment of Summers's thesis must take into account how large a number of the most prestigious law schools, from which many of the nation's future leaders are likely to be drawn, would lack substantial minority representation.

Summers's argument does not, in any event, speak to the constitutional issue since, as he acknowledges, absent a large infusion of government funds, racial and ethnic preferences in the award of financial assistance must continue if minority enrollments are to be maintained. Id. at 398-401.

118 Even if the Supreme Court were to adhere to the notion that all racial and ethnic classifications are constitutionally "suspect" (but see note 91 supra) the argument supporting preferential admissions policies should be sufficient to sustain their validity. A conclusion that a classification is constitutionally suspect triggers closer judicial scrutiny to assure that (1) the interests served by the governmental action are of "compelling" importance, and (2) there is no more precise means by which the government can accomplish its objectives. See, e.g., In re Griffiths, 413 U.S. 77 (1973); Dunn v. Blumstein, 405 U.S. 330 (1972). The latter requirement, as the discussion in the text demonstrates, is plainly satisfied. Preferential admissions policies are aimed with precision at their objectives. The difficult question is whether that objective is "compelling." Precisely how courts are to make that judgment remains a mystery, but it is hard to imagine that any policy would fail to qualify that offers promise of contributing to a solution of the nation's most enduring social problems. $C f$. Kahn v. Shevin, 416 U.S. 351 (1974). 


\section{Political Responsibility and the Judicial Role}

Professor Ely also concludes that minority preferences in state colleges and universities should not be held beyond the power of government, but he reaches the conclusion by a quite different argument from that developed in the preceding pages. Curiously, his argument raises what are, for me, the most troublesome questions about the validity of existing preferential admissions programs. ${ }^{119}$

Ely's premise is the familiar view that in determining the constitutionality of legislation courts owe less than normal deference to legislative judgments when the interests of a minority are uniquely threatened. Although he is seemingly prepared to have the courts subject a legislative judgment to closer than normal scrutiny whenever any minority is singled out for disadvantageous treatment, ${ }^{120}$ Ely employs the distinction primarily to explain why courts are justified in examining with special care legislation that employs a racial classification to the detriment of a minority. The reason, he argues, is that there is less basis than normally exists to have confidence in the legislature's assessment of the costs and benefits of the legislation. When the impact of legislation is broadly distributed through the society there is no reason to suspect inaccuracy in the legislature's measurement of costs and benefits. Similarly, when legislation distinguishes between two minorities (say, optometrists and opticians), there is no reason to suppose that the legislature's assessment of costs and benefits has been inaccurate. When, however, the costs and benefits of legislation are differentially distributed between a (racial) majority, to which most members of the legislature belong, and a minority, the legislature's assessment of these costs and benefits is likely to be distorted. The legislature's exclusive identification with the group to which most of its members belong, Ely contends, will tend to distort its assessment in two ways: first, by leading it to overestimate the costs of treating the majority and minority equally, and, second, by causing it to undervalue the costs imposed upon the minority by the differential treatment. Both of these risks are enhanced by the existence of racial prejudice. ${ }^{121}$

This analysis leads Ely to conclude that there is no reason for a court to view as constitutionally "suspect" a racial classification

'1' The argument presented in this section requires a good deal more elaboration than is possible within the confines of this paper. It is, however, of sufficient importance to the issues posed by preferential admission policies that a sketchy treatment seems better than none. I hope to develop the argument in greater detail in subsequent work.

${ }^{120}$ See Ely, supra note 2, at 734 .

121 Id. at 728-33. 
adopted by a majority "so as to advantage a minority and disadvantage itself ....

A White majority is unlikely to disadvantage itself for reasons of racial prejudice; nor is it likely to be tempted either to underestimate the needs and deserts of Whites relative to those of others, or to overestimate the costs of devising an alternative classification that would extend to certain Whites the advantages generally extended to Blacks. ${ }^{122}$

The same argument leads Ely to conclude that minority preferences are not constitutionally infirm.

Ely's analysis and the conclusions he draws from it are troublesome on several grounds. First, in American politics majorities are rarely if ever monolithic. ${ }^{123}$ Typically, political majorities are coalitions of minorities which have varying interests in the issue presented for decision. The real dispute is not between a majority and a minority but between those minorities whose interests are most immediately affected. Resolution of the dispute depends upon which of the minorities is more successful in forging an alliance with those groups which are less immediately affected.

The issue whether state schools ought to adopt preferential admissions policies is no exception. The immediate beneficiaries of these policies are the minorities which receive preferential treatment. But there is no reason to suppose that the costs of such policies are borne equally by sub-groups within the white population. To the extent that they are not, the discrimination-though nominally against a majority-is in reality against those sub-groups. ${ }^{124}$

122 Id. at 735; $c$. P. Kurland, Politics, the Constitution, AND the WarRen Court 159 (1970): "[e]nactment of legislation favoring a minority may be treated as . . . a waiver by the majority of its right to equal treatment."

123 See R. Dahl, A Preface to Democratic Theory (1956).

${ }^{125}$ Ely recognizes this possibility but ultimately fails to come to terms with it. The concern that the burden of racial and ethnic preferences will fall disproportionately upon a sub-group of whites has, as Ely notes, been particularly strong among segments of the Jewish population. Ely responds to that concern by arguing that a policy of racial and ethnic preferences does not justify discrimination against Jews or any other group for those places in the class unaffected by the preference. If the heightened pressure on admissions brought about by racial and ethnic preferences leads to discrimination against Jews, the courts should intervene on their behalf. Ely, supra note 2, at 736-38.

Ely's response is correct, as far as it goes, but it does not meet the real problem. Racial preferences may disproportionately burden certain groups even though they do not lead to overt or conscious discrimination against them. My own guess, and it is only that, is that the primary burden of existing racial and ethnic preferences falls not upon Jews, but upon the white working class whose children find it more difficult to obtain financial aid because of the preferences given to minority groups. Whether or not distribution of the burden is skewed in this way, there is no reason to suppose that the white professoriate primarily 
The fact that the costs of racial and ethnic preferences are not equally or randomly distributed among the white majority is not, by itself, a basis for constitutional objection to the preferences. The costs of governmental policies often fall disproportionately upon sub-groups in the society. In the absence of a constitutional norm insulating a group from that burden, there is no warrant for judicial intervention. ${ }^{125}$ The distribution of burdens and benefits is the central function of the legislative process.

The legitimacy of the legislative process does not depend upon the disinterestedness of the legislature, as Ely implicitly argues, but upon its political responsibility. Legislatures are, no doubt, not fully responsive to the wishes of the electorate-nor would we want them to be-but their political responsibility is crucial to the democratic ideal that governmental policies ought to respond to the wishes of the citizenry. The legislature's political responsibility serves that ideal in a number of ways. First, it provides a means by which government is made more sensitive to the impact of a policy upon the various segments of the society and thereby contributes to the calculation of gains and losses resulting from that policy. Second, since an appraisal of the consequences of policy involves not merely a measurement of gains and losses, but a judgment of what is to count as a gain or loss and how these shall be balanced, political responsibility helps ensure that governmental policy will not depart too far from the values of the citizenry. Finally, the political responsibility of the legislature creates an incentive for compromise and accomodation that facilitates development of policies that maximize the satisfaction of constituents' desires.

It is precisely these legitimating characteristics of the legislative process that lead to my doubts about the validity of existing preferential admissions policies. Those policies are not the product of a politically responsible legislative body, but of decisional processes internal to the universities that have adopted them. Decisions to employ racial and ethnic preferences have either been made by faculties or by the governing bodies of the institutions. In either event, the process of decision and the character of the decisionmaking body are very different from those of legislatures, different in ways that ought to make the courts a good deal less confident about the propriety of those policies than would be justified if they had been adopted by a legislature.

responsible for adopting preferential policies identifies more closely with excluded white applicants than with the preferred minorities.

${ }^{125}$ See note 21 supra. 
A law school faculty, for example, is not well situated to acquire information about the impact of its decisions upon persons outside the law school community and the legal profession. Nothing in the relationship of the faculty to the public makes it likely that the faculty will learn whether a decision to grant preferences to certain racial or ethnic groups imposes unduly heavy costs upon other groups in the society or whether there are still other groups that might plausibly lay claim to a similar preference. ${ }^{126}$ Of course, law faculties are not wholly insulated from outside pressures, but their processes of decision are a good deal less likely than those of legislatures to elicit such information. Faculties are, moreover, less constrained than legislatures by the need to obtain public consent for their actions, creating a danger that the choices they make will depart too widely from the values of the larger society. This danger is enhanced by the fact that, for all their diversity, faculties are relatively insular communities, subject to distinctive pressures and a tendency to form distinctive outlooks upon issues. Encompassing less diversity than the larger population, they are relatively more prone to fall victim to those enthusiasms and waves of passion that befall small groups ${ }^{127}$ and justify lodging decision-making authority in larger groups. ${ }^{128}$

These considerations need not be a source of concern when, as will normally be true, faculty decisions are made within the framework of societal consensus, but they are a good deal more troublesome when, as in the case of racial and ethnic preferences, a consensus does not exist. The absence of a consensus is of particular concern because the question whether preferences shall be used poses major value choices for the society. Minority preferences may, as I have argued, serve deeply rooted societal values. But there is a risk, the dimensions of which cannot yet be fully understood, that they will do so at a significant sacrifice of other values.

One major area of concern is the impact preferential policies may have upon the relationship among racial and ethnic groups. It may be, as some have suggested, that "we can have a color-blind society in the long run only if we refuse to be color-blind in the short

${ }^{126}$ For an intimation that the University of Washington Law School did not even consider whether Orientals should have been accorded the benefits of its preferential admissions policy, see Morris, Equal Protection, Affirmative Action and Racial Preferences in Law Admission: DeFunis v. Odegaard, 49 Wash. L. Rev. 1, 50 (1973).

127 The sense of William Buckley's familiar quip that he would rather be governed by the first 2,000 persons listed in the Boston telephone directory than by the Harvard faculty derives from such considerations.

${ }^{123}$ Cf. The Federalist No. 10 (J. Madison). 
run." 129 But there is a danger that the use of preferences will exacerbate existing tensions in the society, both by creating resentment against the preferred groups, ${ }^{130}$ and by buttressing existing identifications and loyalties. The current beneficiaries of preferential policies may have a compelling claim to them, but, given the incentives, other groups may be expected to come forward with claims that, to them at least, will seem equally compelling. Since groups that currently benefit from preferential policies are no more likely than the beneficiaries of other subsidies to relinquish them willingly merely because the needs by which they were originally justified have become less acute, ${ }^{131}$ the claims of other groups to similar preferences are likely to become increasingly justifiable over time. Significantly heightened racial and ethnic tensions would follow, as various groups in the society vied for their "rightful share" of university admissions and other social goods.

How seriously one takes these possibilities depends not only upon an estimate of the likelihood of their occurrence, but upon one's vision of the ultimate goal. All would agree that an intensification of racial and ethnic identifications and loyalties to the point where coexistence is threatened would be undesirable. Yet there is currently a good deal of disagreement about whether social policy should aim toward a fully integrated society - at the extreme, a society in which all racial and ethnic identity is lost-or a multiethnic, multi-racial society in which the lives of many individuals would center upon their group identification. Adherents of one or another of these positions (or of some intermediate view) are, one suspects, likely to weigh the prospects of group conflict very differently.

More fundamentally, these positions reflect differing views about the desirable organization of society and the place of the individual in it. Movement toward a society organized along racial and ethnic lines may be seen as posing a serious threat to concepts of individuality that-though they have often been honored only in

ia B. Bittker, The Case For Black Reparations 120 (1973).

130 Kaplan, supra note 28 , at 376 . The danger is, arguably, increased by the fact that the use of different admissions standards for minority applicants and others is likely to produce students from the two groups of markedly differing abilities, thereby reinforcing stereotypes of racial or ethnic inferiority whose breakdown is not yet entirely secure. Id. at 378; Graglia, supra note 92, at 356. Although that danger ought not to be ignored, "[t]he question," as Professor Ely wisely observes, "is whether the negative effects of using racial criteria to overcome centuries of discrimination are so inevitable, and indeed so threatening, as to outweigh the good that such programs may accomplish." Ely, supra note 2, at 739.

'31 Kaplan, supra note 28, at 376-77. 
the breach-lie at the base of American beliefs and institutions. ${ }^{132}$ The extent to which the society will move in that direction will be primarily determined by forces other than those set in motion by preferential admissions policies, but, given the importance of the universities in contemporary America, the policies they pursue are likely to be a factor in determining society's direction.

These considerations do not, in my judgment, disturb the earlier conclusion that the courts ought to reject a constitutional rule precluding legislatures from adopting racial and ethnic preferences. Balancing the dangers of these preferences against their potential gains is a delicate, and ultimately legislative, task. There is no warrant for the courts to draw the issue from the political forum. The DeFunis case, however, did not on its facts require a judgment about whether the courts should invalidate a legislative decision sanctioning minority preferences, nor is it likely that the next case to reach the Supreme Court will do so. Universities have adopted preferential admissions policies without legislative sanction. The precise issue that is raised, therefore, is not whether such policies are valid when adopted by a broadly representative, politically responsible legislature, but whether they are valid when adopted by a university.

Now it may be argued that the source of authority for minority preferences is not relevant to the question whether they should be held to violate the equal protection clause. The question whether law school faculties are authorized to adopt preferential admissions policies is, on this view, solely one of state law: the only federal question is whether the preferential policies violate the equal protection clause, and courts must answer the latter question by proceeding as though the policies had been adopted by or received the express authorization of the legislature. It must be conceded that this is the conventional view of the matter ${ }^{133}$ and that there is support for it in Supreme Court decisions. ${ }^{134}$ The Court's decisions are, however, less clear on the point than might be supposed. The Court has at times indicated that the validity of action taken under the authority of the state may depend upon whether the legislature has made a deliberate and focused judgment that such action is an

${ }_{132}$ Id. at 379-80; Posner, supra note 2, at 9-11.

${ }^{333}$ See, e.g., H. Wechsler, Toward Neutral Principles of Constitutional Law, 73 Harv. L. Rev. 1, 26 (1959).

${ }^{134}$ See, e.g., Uphaus v. Wyman, 360 U.S. 72, 77 (1959); NAACP v. Alabama, 357 U.S. 449, 463 (1957); Minersville School Dist. v. Gobitis, 310 U.S. 386, 597 (1940), overruled in West Virginia State Board of Education v. Barnette, 319 U.S. 624 (1943) (with respect to Barnette, see note 143, infra). 
appropriate exercise of governmental power. ${ }^{135}$

Although these decisions do not overrule the conventional view that the constitutionality of action by a state must be determined without reference to its source within the state, they are supported by more persuasive reasoning. The latter view is based upon the premise that the Federal Constitution does not control the distribution of state legislative authority. The premise is sound, but it does not support the conclusion drawn from it. ${ }^{136}$ The issue is not whether state legislative authority can be delegated, but whether in determining the validity of state action that trenches upon constitutional values, the courts ought to consider whether the judgment under review is that of the legislature or of an agency that is less representative of the public and lacking direct political responsibility. ${ }^{137}$

Minimally, whether challenged state action rests upon a legislative judgment ought to be relevant to the degree of respect shown by the court to the judgment. ${ }^{138} \mathrm{~A}$ commitment to democratic values requires considerable judicial deference to deliberate legislative judgments, rather more in my view than has been customary in recent years. But none of the reasons supporting judicial deference to legislative judgment support equal deference to the judgment of a police department or a law school faculty. And only by ignoring all that we know about legislative behavior could it be supposed that a legislature's failure to limit the power of such bodies is equivalent to affirmative legislative approval of their decisions. ${ }^{139}$

The notion that courts ought to respect all decisions taken under state authority as though they were the product of the most careful legislative deliberation, if consistently applied, would unnecessarily encroach upon constitutional values. Courts would be

${ }_{135}$ See, e.g., Sweezy v. New Hampshire, 354 U.S. 234, 251-55 (1975) (plurality opinion); Stoner v. California, 376 U.S. 483, 488 (1964); Edwards v. South Carolina, 372 U.S. 229, 23637 (1963); Garner v. Louisiana, 368 U.S. 157, 202-04 (1961) (Harlan, J., concurring); Cantwell v. Connecticut, 310 U.S. 296, 307-08 (1940); Gitlow v. New York, 268 U.S. 652, 670-71 (1925).

138 Dreyer v. Illinois, 187 U.S. 71, 83-84 (1902), which has at times been cited in this connection, merely rejected a claim that the state's Indeterminate Sentence Act impermissibly conferred judicial power upon the executive branch of state government. The due process clause, the Court held, did not impose a rule of "separation of powers" upon the states. Dreyer may thus be read as standing for the proposition that the delegation of state legislative power is not prohibited by the Federal Constitution. But it does not support the further proposition that every exercise of state power must be judged under a uniform standard of review.

${ }_{137}$ Cf. Sandalow, The Limits of Municipal Power Under Home Rule: A Role for the Courts, 48 MinN. L. REv. 643, 692-721 (1964).

13* See C. Black, Structure and Relationship in Constitutional Law 67-98 (1969).

139 See, e.g., Choper, The Supreme Court and the Political Branches: Democratic Theory and Practice, 122 U. PA. L. Rev. 810 (1974). 
required to sustain the constitutionality of governmental action that, because of the political safeguards of the legislative process, might fail to receive legislative approval. Conversely, if judicial determinations of constitutionality are in reality influenced by an agency's lack of political responsibility, the failure of constitutional doctrine to acknowledge that fact candidly would lead to inappropriate restrictions on legislative power: a decision that certain action is unconstitutional when taken solely on the authority of, say, a police officer will be understood to mean that such action would be unconstitutional even if sanctioned by the legislature. ${ }^{140}$ In short, both the adequate safeguard of constitutional values and appropriate respect for legislative competence require abandoning the view that all policy decisions are to be reviewed with equal deference; regardless of their source.

The need for judicial attention to the political responsibility of the source of allegedly unconstitutional state action is supported by another and equally fundamental consideration. The blithe references to "constitutional values" in the preceding discussion ought not to obscure the fact that the values that receive constitutional protection change over time. Constitutional law evolves to reflect the changing circumstances and values of our society. Few would wish it otherwise. Yet, after nearly two centuries experience the courts have not succeeded in identifying sources of constitutional judgment that will, in a phrase of Alexander Bickel's quoted earlier, "securely limit as well as nourish it." 141 This failure stems from the tension between the institutional mechanism that has developed for giving meaning to the Constitution-judicial review-and the democratic ideal that politically responsible institutions should determine the direction of governmental policy. Quite possibly, that tension can never be completely eliminated. It might, however, be substantially reduced by the development of doctrines that place primary responsibility upon the legislature for making critical choices. ${ }^{142}$ When such choices must be made, the effort ought to be

${ }^{100}$ Cf. Burt, Miranda and Title II, A Morganatic Marriage, 1969 Sup. Cr. Rev. 81; Sandalow, supra note 137 , at $685-92$.

i11 See note 73 supra.

112 The familiar maxim that statutes should be construed to avoid constitutional questions serves an identical purpose in relation to federal executive action. See, e.g., Greene v. McElroy, 360 U.S. 474 (1959); Kent v. Dulles, 357 U.S. 116 (1958). The underlying notion is not merely that Congress should not be assumed to have authorized action which trenches upon fundamental values, but that in assessing the competing claims of important values that have come into collision, the judgment of Congress is of critical importance. 360 U.S. at 506-07. 
to draw from the legislature, as the most broadly representative, politically responsible institution of government, a focused judgment about the appropriate balance to be struck between competing values. ${ }^{143}$ Once the legislature has made such a judgment, courts ought to be extremely hesitant to upset it, for if the values to which law gives expression are to change over time, the legislature's warrant for making the necessary decisions is a good deal stronger than that of the courts. In the absence of such a judgment, however, democratic values require invalidating an exercise of state power that undermines values traditionally viewed as fundamental. The cause of democracy is not served by allowing a subordinate state agency to make such decisions.

These considerations frame the issues that are posed for the courts by current policies of racial and ethnic preferences in university admissions. There is no warrant for a judicially imposed rule foreclosing legislative authorization of such policies. The difficult question is whether those policies ought to be held to be within the competence of a university. If the analysis advanced here were to be adopted by the courts, the judicial answer to that question would only determine whether the proponents or opponents of minority preferences would bear the burden of seeking legislative action. U1timate authority over a critical issue of social policy would be consigned to the legislature as the most broadly representative, politically responsible institution of government. A judicial decision concerning the university's authority would, nevertheless have considerable significance. Although neither proponents nor opponents of minority preferences lack the means to force serious legislative consideration of the issue, ${ }^{144}$ the difficulty of obtaining legislative action

${ }^{163}$ It is worth noting that in West Virginia Board of Education v. Barnette, 319 U.S. 624 (1943), the Court rested in part upon just such a consideration in overruling its earlier decision in Minersville School District v. Gobitis, 310 U.S. 586 (1940). In the earlier case, Mr. Justice Frankfurter, writing for the Court, had said that the decision of a local school board to require children to salute the flag "must be viewed as though the legislature had itself formally directed the flag-salute . . . ." Id. at 597. In Barnette, by contrast, Mr. Justice Jackson wrote for the Court:

Such Boards are numerous and their territorial jurisdiction often small. But small and local authority may feel less sense of responsibility to the Constitution, and agencies of publicity may be less vigilant in calling it to account. The action of Congress in making flag observation voluntary and respecting the conscience of the objector in a matter so vital as raising the Army contrasts sharply with these local regulations in matters relatively trivial to the welfare of the nation.

i' There are situations in which serious legislative consideration of an issue is unlikely to result from the political process, as when the persons or interests adversely affected by a governmental policy are too small in number to capture the attention of the legislature or are so widely diffused through the population as to make the cost of political organization prohibitive. In such cases judicial invalidation of the policy may serve a useful purpose by 
on so highly charged an issue would place the side bearing that burden at an important disadvantage. The。question for the courts is which side ought to bear the burden.

The answer one gives to that question is likely to depend upon how one reads our constitutional tradition with respect to racial and ethnic discrimination. If that tradition is understood to flow primarily from egalitarian values, a concern that government ought not to contribute to the subjugation of minorities, there is little reason to deny universities the power to adopt preferential policies. Existing preferences seem likely to move the nation toward the goal of racial and ethnic equality. Such preferences are likely to be seen as contrary to constitutional tradition, however, if the tradition is understood to be rooted primarily in an ethic of individualism, a belief that each individual ought to be judged solely on his own merit. ${ }^{145}$ The difficulty, in my view, is that neither alternative is entirely accurate. Our constitutional tradition reflects both egalitarian and individualist values because until recently the two seemed entirely compatible. Now, for the first time, it appears (to many) that at least in the short run a choice may be required.

In the absence of a guiding constitutional tradition, I would conclude that two arguments call for a decision sustaining the power of universities to adopt preferential admissions policies. The dispute over racial and ethnic preferences involves a conflict between values of a very high order. Such conflicts are never fully resolved. The practical question is how far the society will move in one direction or the other. Although the admissions policies of universities are not a negligible factor in determining that direction, their ultimate importance should not be overstated. There are many other points of decision within the society, including private enterprise and other government agencies. Moreover, the system of higher education is itself highly decentralized. When a value choice of such magnitude is posed, and especially when the need for choice has only recently become apparent so that its dimensions are not fully understood, there may be wisdom in allowing for a period of decentralized

affording the legislature a practical opportunity to speak to the issue. There is no reason to suppose that either side of the racial preference issue lacks effective access to the legislature.

iss It is a measure of the complexity of the issues raised by minority preferences that they can also be viewed as a threat to egalitarian values, see note 130 supra, and as necessary to the establishment of conditions that will maximize the opportunities for individual development, see text and note at note 106 supra. The fact that both values can plausibly be invoked either in support of or in opposition to preferential policies cautions against too ready acceptance of the common assumption that equality and individualism are at opposite ends of a single continuum. 
decision-making. Universities have, in fact, responded to the demands for increased minority enrollments in a variety of ways. Some have adopted racial and ethnic preferences. Others have adopted policies of preference for the disadvantaged without regard to racial and ethnic background. Still others have adopted policies of "open enrollment." Finally, some have maintained traditional "color-blind" standards. This diversity of approaches may generate a better understanding of the issues, permitting development of a consensus which is now lacking.

The most compelling reason for sustaining preferential admissions policies is that they offer hope of ameliorating the nation's most enduring problem. The contrary arguments cannot be taken lightly; racial and ethnic preferences do involve serious dangers. In the end, however, a decision concerning their validity cannot avoid a judgment about whether they are likely to contribute to or retard development of the kind of society we want. In my own judgment, for reasons already explained, the former is more likely. It would be foolish to assert that judgment confidently, however. If the potential benefits are great, so too are the potential losses. But in the light of the seriousness of America's racial problem, the risk seems worth taking, however uncomfortable we may be with it.

So speculative and personal a judgment is a weak foundation for judicial interpretation of the Constitution. Yet, a contrary decision would necessarily rest upon predictions that are equally conjectural and, therefore, equally personal. If judges are uneasy about resting constitutional interpretation upon such foundations, the remedy is not to fashion principles that mask the underlying choices. The remedy, rather, is candidly to avow the choices that must be made and to develop doctrines that consign ultimate authority for those choices to the legislature, where in a democracy it rightly belongs..$^{146}$

${ }^{148}$ Of course, even on a conventional constitutional analysis, a decision sustaining existing minority preferences would have that effect. 